Gianluca Miniaci

\title{
Reuniting Philology and Archaeology: The "Emic" and "Etic" in the Letter of the Dead Qau Bowl UC16163 and its Context
}

DOI 10.1515/zaes-2016-0007

Summary: The present article aims to combine an accurate philological analysis of the letter to the dead UC16163 and its archaeological context. The letter is a double document containing two letters addressed by Shepsi to both his dead parents (Iinkhenmut and Iy). In fact, the letter was found in an undisturbed tomb, no.7695, in the necropolis of Qau, where only a single male deceased lay in the funerary chamber, with no evidence/traces of any further interment or later disturbance. According to the text of the letter, one would expect two internments inside the tomb, Shepsi's father and mother. The discrepancy between the content of the letter and the archaeological evidence is remarkable. However, the new philological reading here proposed sheds new light on the role of Shepsi's brother, Sobekhotep, switching his role from the dangerous, as previously interpreted, to simply negligent dead. Sobekhotep is the prime element in both texts and he is the last person to have died in Shepsi's family, as in many points evident in the two letters. The particular emphasis of the episode of the funeral/burial of Sobekhotep reveals that Shepsi is addressing directly to his brother. The new interpretation of the text seems to support the idea that the deceased found together with the bowl in Qau tomb 7695 is Sobekhotep himself.

Keywords: Emic - etic - letters to the dead - bowl - Qau Petrie excavations - First Intermediate Period - funerary archaeology - judgment from thereafter - ancestor - family dispute - burial practice - passive perfective

In his synthesis of European prehistory Gordon Childe as an archaeologist with a strong interest for comparative linguistics, felt the need to separate philology and archaeology in two different strands, giving birth, either consciously or unconsciously, to two differently-focussed books, “The Dawn of European Civilization” (1925), based

Gianluca Miniaci

Ecole Pratique des Hautes Etudes, Paris

Email: gianluca.miniaci@ephe.sorbonne.fr on archaeological analysis, and "The Aryans: a Study of Indo-European Origins" (1926), based on more speculative linguistic interpretations ${ }^{1}$. At the same time, however, he showed the potential for combining philology and archaeology to open new horizons of research and for offering original ideas. Although from the early 1980s onwards, the interest of archaeologists toward philology and language notably increased ${ }^{2}$, nevertheless the difficulties in finding a common perspective as well as the high degree of specialization required, hardly supported an organic fusion between the two disciplines ${ }^{3}$.

A corpus of Egyptian texts known as "Letters to the Dead" demonstrates the benefit of combining what can be "seen" in the archaeological record with what can be "heard" from ancient writings, taking advantage of two different points of view used in anthropology: the 'emic' and the 'etic'.

\section{The 'insider' and 'outsider'}

'Emic' and 'etic' are terms borrowed from the linguistic, by subtracting the prefix phon-from the words phonemic and phonetic thus converting them into 'emic' and 'etic'. These are used in anthropology to refer to two types of data concerning human behaviour. As defined for social science by the linguist Kenneth Pike, the term 'emic' describes the analyses and the accounts based on the internal point of view of native members of the culture whose beliefs and behaviours are being studied. The emic approach aims to explore how people think, how they perceive and categorize the world, from the internal perspective of the observed community ('insider'). On the other hand, the term 'etic' describes the analyses and the accounts based on the point of view of a community of scientific observers (i.e.

1 Trigger 1980, 37-53.

2 Colin Renfrew, who attempted to create a holistic synthesis between language and archaeology in the 80s, seemed in the end to drag philology out of archaeology: "it is too early yet to offer a convincing synthesis between the new linguistic and archaeological approaches”, Renfrew 1987, 7, 285. Cf. Trautmann, Sinopoli 2006, 209. 3 Blench, Spriggs 1999. 
external perspective to the native members) ${ }^{4}$. The etic approach shifts the focus from local observations to those of an external investigator ('outsider'). By the end of 1980s, the terms widespread in many academic disciplines other than linguistics and anthropology, being frequently used in psychology, sociology, medicine, education, management, etc ${ }^{5}$. Applying these interpretative categories to the study of ancient societies, the emic knowledge would concern the sources that allow us to explore the most immediate communicative methods of ancient people (written sources), while etic knowledge concerns the sources that an outsider (researcher) can use to build his interpretative approach, free from ancient "voices". Defined in these terms, philology could be intended as the emic approach, which aims to explore what some insiders (ancient societies) thought, and consequently explicitly wrote down, while archaeology can be perceived as the etic procedure, in which a silent material must necessarily be interpreted by outsiders (researchers) ${ }^{6}$. The practice of reuniting in a single unit archaeology and philology allows us to simultaneously "see" and "hear" past societies".

Table 01: Division between 'emic' and 'etic'.

\begin{tabular}{ll}
\hline Emic & Etic \\
\hline 'Insider' & 'Outsider' \\
\hline Observed & Observers \\
\hline Speech > Word & Object \\
\hline Hearing > Reading & Seeing \\
\hline Philology & Archaeology \\
\hline
\end{tabular}

4 Pike 1954; Pike 1979, 1-36; Harris 2001.

5 Headland 1990, 13-27.

6 The debate on the correct use of emics and etics is still open and no clear borderline between emic and etic knowledge exists, since the emic and etic perspective changes the point of view of a phenomenon (epistemology), but not the essence of the phenomenon itself (ontology), Lett 1990, 132; and, in any case, for past societies the etic approach requires inevitably interpretation from an external observer. 7 This division is the basis of a European project, SHAPE (acronym of "Seeing and Hearing the Ancient Producers of Egypt"), I started at the École Pratique des Hautes Études in Paris, which aims to define the circulation of knowledge within the sphere of material production in Middle Kingdom Egypt (2000-1550 BC). The identification of linguistic and conceptual categories active within the ancient horizon of the producers/consumers themselves will allow us to define the interconnectivity between the commissioners (who commissioned and imagined the material production) and the material creators (craftsmen, artists, artisans).

\section{A syntagmatic relation}

In 1914 an unusual text inscribed on a band of linen caught the attention of Alan Gardiner and Kurt Sethe, who met in London to "discuss a number of different questions of Egyptian philology". The inscription belonged to a category of texts unfamiliar at that time, since they represented short missives written to a deceased person. Gardiner and Sethe collected another eight documents, sharing recurring elements, and classified them as "Letters to the Dead", a definition still in use today ${ }^{9}$. From the first edition of Gardiner and Sethe, published in 1928, other letters have been identified in museums or found in archaeological excavations and today the letter to the dead corpus comprises approximately eighteen documents ${ }^{10}$ :

1) Letter of Irti and Iy to Seankhenptah, Saqqara, Cairo JE25975 ${ }^{11}$;

2) Letter to Pepyseneb, Naga el-Deir $\mathrm{N} 3500^{12}$;

3) Letter of Gef, Sheikh Farag, Boston $13.3791^{13}$;

4) Letter of Heni to Meru, Naga el-Deir N $3737^{14}$;

5) Anonymous letter, Chicago OIM $13945^{15}$;

6) Letter of Merirtyfy to Nebetitef, stela, Harer Family Trust collection ${ }^{16}$;

7) Letter to Nefersekhi, Hu, Petrie Museum UC16244 ${ }^{17}$;

8 Gardiner, Sethe 1928, Preface.

9 Gardiner, Sethe 1928. See also Gardiner 1935, 5-45.

10 Verhoeven 2003, 31-52; Donnat 2010, 71-74, Miniaci 2014a, 39-82, Donnat 2014. The precise number of these letters has yet to be firmly established, because new letters have been recently discovered and added to the corpus, while other documents previously included in such a category seem to fall under other categories.

11 Gardiner, Sethe 1928, 1-3, 13-16. pls. I, IA; Anonymous 1928, 117-119; Gunn 1930, 148-150; Guilmot 1966, 9-11; Wente 1990, 211; Willems 1991, 183-191; Donnat 2009, 61-93; Miniaci 2014a, 41-44; Miniaci 2014b, 27-45; Donnat 2014, 29-35.

12 Simpson 1970, 58-64; Goedicke 1972, 95-98; Quirke 1988, 106107; Wente 1990, 213; Čerwik 1999, 63; Donnat 2012, 237; Miniaci 2014a, 44-46; Donnat 2014, 51-53.

13 Simpson 1981, 173-9; Miniaci 2014a, 46-48.

14 Simpson 1966, 39-52, pls. XLVIA, XLVIB; Roccati 1967, 323-328, tav. I; Fecht 1969, 105-122; Gilula 1969, 216; Simpson 1970, 62; Wente 1990, 212-213; Čerwik 1999, 63; Szpakowska 1999, 163-166; Szpakowska 2003, 24-27, 185; Miniaci 2014a, 48-51; Donnat 2014, 48-51.

15 Gardiner 1930, 19-22, pl. X; Roeder 1961, 269-273; Guilmot 1966, 16-18; Brier 1980, 202; Wente 1990, 213; Janák 2003, 275-277; Teeter 2003, 36-37; Donnat 2012, 231-235; Miniaci 2014a, 51-54; Donnat 2014, 41-44.

16 Wente 1975-1976, 595-600; Wente 1990, 215; Szpakowska 2003, 22-24, 185-186; Miniaci 2014a, 54-56; Donnat 2014, 53-56.

17 Gardiner, Sethe 1928, 5, 20, pls. IV-IVA; Gunn 1930, 151; Guilmot 1966, 13; Roccati 1967, 323-328; Wente 1990, 215; Čerwik 1999, 62; Miniaci 2014a, 56-58; Donnat 2014, 44-46. 
8) Letter of Shepsi to his brother Sobekhotep and his parents, Qau, Petrie Museum UC16163 ${ }^{18}$;

9) Letter to Mereri, Louvre E6134 ${ }^{19}$;

10) Letter of Dedi to Intef, Saqqara, Cairo CG25375; ${ }^{20}$

11) Letter to Sedekh, Berlin $10.482 \mathrm{vs}^{21}$;

12) Letter of Sobekhotep and Waemmut, Qubbet el Hawa, Cairo JE9174022;

13) Anonymous letter, Berlin $22573^{23}$;

14) Letter of Teti-aa, Peet-Rivers Museum 1887.27.124;

15) Letter of Neb to Khnememuaskhet, Pushkin Museum Moscow $3917^{25}$;

16) Letter to Ankhiry, Leiden $371^{26}$;

17) Letter of Butehamun to Ikhtay, Deir el Medina, Louvre $698^{27}$

18) Letter of Iruru to Penhy, Brooklyn $37.1799 E^{28}$.

The medium chosen for this one-side correspondence is varied: pottery elements - bowl, dish, jar stand (10) -

18 Gardiner, Sethe 1928, 5, 20-21, pls. IV, IVa; Gunn 1930, 150-151; Roeder 1961, 273-277; Čzerwik 1999, 62; Wente 1990, 211-212; Donnat 2010, 55-58; Donnat 2012, 237; Donnat 2014, 35-41; Farout 2004, 4252; Miniaci 2014a, 58-63.

19 Piankoff, Clère 1934, 157-169; Guilmot 1966, 11-13; Wente 1990, 214; Donnat 2012, 237; Miniaci 2014a, 63-65; Donnat 2014, 58-61.

20 Gardiner, Sethe 1928, 7-9, 22, pls. VI-VIA; Gunn 1930, 152; Guilmot 1966, 19-21; Wente 1990, 215-216; Fischer-Elfert 1994, 41-44; Čerwik 1999, 64; Donnat 2010, 53-55; Donnat 2012, 237; Miniaci 2014a, 6566; Donnat 2014, 56-58.

21 Grapow 1915, 376-384; Jürgens 1990, 51-63; Miniaci 2014a, 67; Donnat 2014, 63-65. According to Ilona Regulski, none of the phraseology found in this letter can be compared with the other letters to the dead, but its text is definitely inspired by the genre, since it is a request for a child. Another letter, in papyrus Berlin 10481a-b, is also addressed to Sedekh and can be considered a continuation on the dedication of papyrus Berlin 10482vs. This letter closely follows the genre of the letters to the dead, Regulski 2014. I am grateful to Ilona Regulski for discussing this point with me.

22 Edel 1987, 93-105; Seidlmayer 2006, 95-103; Edel 2008, 405-408 (30b/16); Donnat 2014, 67-69.

23 Gardiner, Sethe 1928, 5-7, 21 pls. V-VA; Gunn 1930, 153; Guilmot 1966, 15; Fecht 1969, 114; Wente 1990, 214; Čerwik 1999, 64-65; Donnat 2010, 58-60; Donnat 2012, 237; Miniaci 2014a, 68-69; Donnat 2014, 61 .

24 Gardiner, Sethe 1928, 26. pl. IX.1; Gunn 1930, 153; Wente 1990, 216; Miniaci 2014a, 69-71; Donnat 2014, 69-71.

25 Gardiner, Sethe 1928, 27, pl. IX.2; Gunn 1930, 154; Miniaci 2014a, 71-72.

26 Gardiner, Sethe 1928, 8-9, 23-25, pls. VII-VIII; Gunn 1930, 153; Guilmot 1966, 21-26; Guilmot 1973, 94-103; Schneider 1981; Wente 1990, 216-217; Miniaci 2014a, 72-76; Donnat 2014, 73-77.

27 Černý, Gardiner 1957, pl. 80; Frandsen 1992, 31-49; Černý 1973, 369-370; Wente 1990, 217-219; Goldwasser 1995, 191-205; Miniaci 2014a, 76-79; Donnat 2014, 77-80.

28 Janson, Vittmann 1992-93, 23-43, pls. 2-3; Donker van Heel, Golverdingen 2003, 25; Miniaci 2014a, 80-82; Donnat 2014, 80-83. papyrus (5), linen (1), stela (1), and ostracon (1). Sylvie Donnat has recently identified other categories of letters to the dead written with different stylistic structures and language regimes onto different objects such as figurines and statues ${ }^{29}$. Although the corpus stretches from the Old Kingdom to the seventh century BC, most of the letters belong to a narrow segment of time, between the end of the Old Kingdom/First Intermediate Period and the early Middle Kingdom ${ }^{30}$. The reason for writing texts to the dead does not lie in the desire to communicate with the beloved deceased, but rather to elicit help from the dead. The letters are not addressed by the living to ancestor figures, but to recently deceased members of the family, requesting their help from the netherworld for practical and urgent problems, ranging from illness to disputes over property ${ }^{31}$. The dead person is expected to intervene from the afterlife to prevent the writer's suffering.

Some letters were purchased and their provenance remains unknown; others come from funerary contexts, found in tombs or funerary chambers deposited with the deceased. Only seven letters have a precisely documented archaeological context, and for two of these the name of the owner of the funerary structure corresponds to the addressee of the letter. Unfortunately, for the other five letters, no owner's name is attested/preserved in the archaeological context, or recorded in the excavator's account. This statistic, although derived from a very low number of documents, does reveal that up to $100 \%$ (2/2) relate to "sameness" between the deceased and the addressee of the text. An eighth letter, written on the verso of a stela of unknown provenance, refers to the same name, Nebetief, carved on the recto of the stela itself. In all probability, the stela was placed inside the funerary space of the deceased herself; hence, it might be assumed that the owner of the tomb (=owner of the stela) is identical to the addressee of the letter. This further example reinforces the idea of an interwoven relationship between the letter and its spatial arrangement, and leads one to postulate about a "syntagmatic relation" between the act of writing the letter and the act of depositing it inside a funerary structure; the content of the letter and the place where it was found constitute an inseparable unit. In simpler terms, the letter, once written down, was actually placed inside the tomb of the deceased, to whom it was addressed. Although such a relationship sounds quite axiomatic, nevertheless, one of these documents, the letter of Shepsi (UC16163), is dissonant, since the text of the letter does not find an imme-

29 Donnat 2014, docs. 12, 13, 16.

30 Moreno Garcia 2010, 138-139.

31 Willems 2008, 192-193. 
diate cross-validation with its archaeological context. The letter of Shepsi is addressed to his deceased parents (father and mother), while in the tomb where the letter was placed only a single male deceased was found with no evidence/traces of any further interment or later disturbance.

Table 02: List of letters coming from a documented archaeological context and the correspondence between the name of the deceased where the document was found and the addressee of the letter.

\begin{tabular}{|c|c|c|c|c|c|}
\hline No & $\begin{array}{l}\text { Documents } \\
\text { with precise } \\
\text { finding-con- } \\
\text { text }\end{array}$ & Addressee & $\begin{array}{l}\text { Place of } \\
\text { discovery }\end{array}$ & $\begin{array}{l}\text { Owner of } \\
\text { the funerary } \\
\text { structure }\end{array}$ & $\begin{array}{l}\text { ID } \\
\text { match- } \\
\text { ing }\end{array}$ \\
\hline 1 & $\begin{array}{l}\text { Letter Cairo } \\
\text { JE25975 } \\
\text { (doc. no. 1) }\end{array}$ & $\begin{array}{l}\text { Seankh- } \\
\text { enptah (M) }\end{array}$ & $\begin{array}{l}\text { Mastaba } \\
\text { (Saqqara) }\end{array}$ & $\begin{array}{l}\text { "Controller } \\
\text { of Night } \\
\text { Bark" and } \\
\text { "Controller of } \\
\text { the Day Bark" } \\
\text { Seankhenptah } \\
\text { (M) }\end{array}$ & YES \\
\hline
\end{tabular}

2 Letter Nag Pepyseneb, Tomb N Not present/ ed-Deir N3500 son of 3500 (Nag not stated in (doc.no. 2) Hetepneb(i) ed-Deir) the report

(M)

\begin{tabular}{|c|c|c|c|c|c|}
\hline 3 & $\begin{array}{l}\text { Letter Boston } \\
13.3791 \\
\text { (doc.no. 3) }\end{array}$ & Gef (?) (M) & $\begin{array}{l}\text { Tomb } 200 \\
\text { (Sheikh } \\
\text { Farag) }\end{array}$ & $\begin{array}{l}\text { Not present/ } \\
\text { not stated in } \\
\text { the report }\end{array}$ & - \\
\hline 4 & $\begin{array}{l}\text { Letter Boston } \\
38.2121 \\
\text { (doc. no. 4) }\end{array}$ & Meru (M) & $\begin{array}{l}\text { Enclosure } \\
\text { of tomb N } \\
3737 \text { (Nag } \\
\text { ed-Deir) }\end{array}$ & $\begin{array}{l}\text { "Prince", } \\
\text { "count", } \\
\text { "overseer of } \\
\text { the priests" } \\
\text { Meru (M) }\end{array}$ & YES \\
\hline 5 & $\begin{array}{l}\text { Letter } \\
\text { UC16244 } \\
\text { (doc. no. 7) }\end{array}$ & $\begin{array}{l}\text { Nefersekhi } \\
\text { (M) }\end{array}$ & $\begin{array}{l}\text { Cemetery } Y \\
(\mathrm{Hu})\end{array}$ & $\begin{array}{l}\text { Not present/ } \\
\text { not stated in } \\
\text { the report }\end{array}$ & - \\
\hline 6 & $\begin{array}{l}\text { Letter } \\
\text { UC16163 } \\
\text { (doc. no. 8) }\end{array}$ & $\begin{array}{l}\text { linkhenmut } \\
\text { (M) and ly (F) }\end{array}$ & $\begin{array}{l}\text { Tomb } 7695 \\
\text { (Qau) }\end{array}$ & $\begin{array}{l}\text { Single } \\
\text { deceased } \\
(\mathrm{M}) \text { - no } \\
\text { traces of other } \\
\text { interments }\end{array}$ & NO \\
\hline 7 & $\begin{array}{l}\text { Letter Caire JE } \\
91740 \\
\text { (doc. no. 12) }\end{array}$ & $\begin{array}{l}\text { Father of } \\
\text { Sobekhotep } \\
\text { (M) }\end{array}$ & $\begin{array}{l}\text { Tomb 30b } \\
\text { (Qubbet } \\
\text { el-Hawa) }\end{array}$ & $\begin{array}{l}\text { Not present/ } \\
\text { not stated in } \\
\text { the report }\end{array}$ & - \\
\hline $8^{*}$ & $\begin{array}{l}\text { Letter private } \\
\text { collection } \\
\text { Harer Family } \\
\text { Trust } \\
\text { (doc. no. 6) }\end{array}$ & Nebetief (F) & $\begin{array}{l}\text { Unknown - } \\
\text { letter } \\
\text { written on } \\
\text { a stela }\end{array}$ & $\begin{array}{l}\text { The stela } \\
\text { belongs to a } \\
\text { woman called } \\
\text { Nebetief (F) }\end{array}$ & YES \\
\hline
\end{tabular}

Reading the letter of Shepsi in a different light and combining it with the archaeological information, it is possi- ble to offer an alternative, unprecedented, but plausible scenario.

\section{Letter of Shepsi, Qau bowl - UC16163}

\section{The etic ('what we can see'): the archaeological context}

The letter, written on a bowl, was found in 1924 by Noel Wheeler, while excavating on behalf of Flinders Petrie in the southern cemetery of Qau (west part), a modern village in Upper Egypt, south of Asyut, corresponding to ancient Antaeopolis. The South Cemetery was included in those cemeteries excavated by or under the supervision of Petrie and located in the proximity of Qau bay ${ }^{32}$. All the tombs found within this cemetery were labelled under the 7000 numbering system according to Brunton's arrangement (i.e. each tomb number was prefixed by number 7). According to the excavation report, the bowl UC16163 was found in an undisturbed context, inside the shaft tomb $695^{33}$. The bowl was deposited in the burial opening on the south side of a shallow shaft (3,5 m), behind the head of a male deceased: "7695. Chamber on south, not disturbed, containing the body of a man, feet crossed, hands down, facing east. In the north-east corner of the room three pots, all before the $\mathrm{IX}^{\text {th }} \mathrm{dyn}$. Behind the head, red pottery bowl covered inside and outside with hieratic"34. As also reported in the tomb register ${ }^{35}$ and in the tomb-cards, filled in at the time of the discovery, the tomb was found intact (see Figs. 01-02). A brick closing wall was recorded in front of the entrance to the burial chamber, but in the published report, its state of preservation at the time of the discovery appears unclear (intact/partially intact/only traces?):

\footnotetext{
"The brick walling of the room was not recorded as being intact when found, and we have, therefore, no evidence as to whether the tomb was re-opened after the burial to allow of the inscribed bowl being deposited. But it seems unlikely that the shaft would have been emptied and the wall below broken and repaired to allow this to be done" 36 .
}

Although Brunton explicitely states that the closing wall was not recorded as intact, the last sentence implies that it was found upright (hence intact?) at the moment of dis-

32 Brunton 1927, 3.

33 Brunton 1927, pl. III; Kemp 1975, fig. 9.

34 Brunton 1927, 37

35 Brunton 1928, pl. LXIII.

36 Brunton 1927, 37. The underline is mine. 
covery, an evidence supported by the absence of shaft-filling inside the burial chamber:

"If the bowl was put in position subsequent to the burial, the shaft must have been at least partially cleared to give access, and the brick wall broken and repaired again, to keep out the shaft-filling" ${ }^{37}$.

In any case, modern disturbance has to be ruled out; ancient disturbance is highly improbable and demands tortuous explanations. Due to the contents of the letter, which mentions two deceased, the excavator explicitly and repeatedly stressed the fact that

"there was no trace of, nor was there room in the chamber for, a second body" ${ }^{38}$,

and later, reporting to Alan Gardiner:

"The chamber was only $21 \mathrm{in}$. wide and $32 \mathrm{in}$. high, so it cannot have been intended for a second burial (of the wife), nor were there any signs of it" ${ }^{39}$.

The tomb card confirms the measurements reported by Gardiner, a chamber of $7 \mathrm{ft} 6$ in $\mathrm{x} 1 \mathrm{ft} 9$ in and high $2 \mathrm{ft} 8$ in (229 cm x $53 \mathrm{~cm} ; 81 \mathrm{~cm}$ high). Indeed, the context was undisturbed and there was no trace of other/later depositions, almost certainly due to the limited room of the chamber which did not allow for any interments other than that of the male deceased found in $\mathrm{it}^{40}$. That is exactly the point of discrepancy between the content of the letter and the archaeological context. The letter, in fact, is a double document containing two letters addressed by Shepsi to both his dead parents, calling them for help in a dispute over his property. On the inside of the bowl, he writes to his father, Iinkhenmut, while on the outside, he turns to his mother, Iy, with a shorter message. Scholars would expect to have found this bowl inside a double burial, containing both the bodies of Shepsi's dead parents. The archaeological reports written by Brunton on the Qau and Badari excavations and the brief report recorded by Gardiner are rigorous in stressing the intact context (no trace of disturbance, presence of the original burial, unbroken entrance sealing), the lack of space for more than one burial, and the firm connection between the bowl and the male deceased, who had the item placed behind his head. The circumstances led scholars to propose various scenarios in order to align the content of the text with the

37 Gardiner, Sethe 1928, 3. The underline is mine.

38 Brunton 1927, 37.

39 Gardiner, Sethe 1928, 3.

40 Brunton 1927, 37. Gardiner, Sethe 1928, 3. archaeological information, as Gardiner and Sethe attempted to:

"the bowl [...] was part of the original burial equipment of a man whom we must suppose to have been the father. Thus Shepśi's troubles would appear to have come to a head immediately after his father's death and before his final interment. The mother must have died earlier, and have been buried elsewhere" ${ }^{41}$.

Table 03: Situation of the tomb 7695 at the moment of discovery.

\begin{tabular}{lllll}
\hline Tomb & $\begin{array}{l}\text { Closing } \\
\text { wall }\end{array}$ & $\begin{array}{l}\text { Disturbance } \\
\text { after the } \\
\text { closure of } \\
\text { the closing } \\
\text { wall }\end{array}$ & $\begin{array}{l}\text { Disturbance before Burial Second } \\
\text { the closing wall } \\
\text { burial }\end{array}$ \\
\hline Qau - found & no traces & $\begin{array}{l}\text { possible but } \\
\text { not recorded by } \\
\text { excavator }\end{array}$ & $1 \mathrm{M}$ & no \\
& & & space \\
\hline
\end{tabular}

\section{The emic ('what we can hear'): the philological content}

The red pottery bowl (h $6 \mathrm{~cm} \mathrm{x} \varnothing 19,5 \mathrm{~cm}$ ) is inscribed with a black-ink, hieratic text in 10 columns on inside and 5 columns on outside, and now part of the Petrie Museum of Egyptian Archaeology collection, UC16163. The lexicography finds a close echo in the Coffin Texts, while the handwriting resembles $6^{\text {th }}$ dynasty Elephantine papyri ${ }^{42}$, suggesting a broad date somewhere between the late Old Kingdom and the Middle Kingdom ${ }^{43}$.

\section{Translation}

\section{Inner side:}

${ }^{(1)}$ (It is) Shepsi ${ }^{\text {(a) }}$ who speaks to his father Iinkhenmut ${ }^{(b)}$ : (2) “This is a reminder ${ }^{(\mathrm{c})}$ of your journey ${ }^{(\mathrm{d})}$ to the fortress (e), to the place where (my) brother < Sobek>hotep ${ }^{(\mathrm{f})}$ was, when I brought to you ${ }^{(\mathrm{g})}$ the foreleg of an ox ${ }^{(3)}$, and when this your son ${ }^{\text {(h) }}$ came with Nuaef ${ }^{(i)}$, and when you said: 'Welcome to me, (my) bro[ther]! (j) Sit and eat ${ }^{\left({ }^{(4)}\right.}$ the meat'. Am I to be injured in your presence, without (anything) being acted for or spoken for this your son by my brother? ${ }^{(\mathrm{k})} \mathrm{I}$ buried him, I brought him from the fort[ress] ${ }^{(1)}$, (5) I placed him among his desert tomb-dwellers, even though thirty measures of Upper Egyptian barley stood against him as a

41 Gardiner, Sethe 1928, 5.

42 Cf. Möller 1912.

43 Gardiner, Sethe 1928, 3. Kemp 1975, 285-286. 
loan (for me) ${ }^{(\mathrm{m})}$ - one loin-cloth ${ }^{(\mathrm{n})}$, one $m n w i{ }^{\left({ }^{(0)}\right.}$ six measures of Upper Egyptian barley, ${ }^{(6)}$ one $\check{s} n s$-shape ${ }^{(\mathrm{p})}$ of linen pack ${ }^{(q)}$, and a $m h_{\text {. }}$-cup $^{(\mathrm{r})}-$, even though I did for him what had never (been) done (before). $\mathrm{He}^{(\mathrm{s})}$ has done this against this your son very wrongfully ${ }^{(t)}(7)-$ although you $^{(\mathrm{u})}$ had said to this your son: 'All my property is vested in my son Shepsi'. See, all my fields have been taken by ${ }^{(8)}$ Sher's ${ }^{(v)}$ son Henu. See, he ${ }^{(w)}$ is with you in the same city ${ }^{(\mathrm{x})} .^{\left({ }^{(9)}\right.}$ Make a judgement together with him now ${ }^{(y)}$, since you ${ }^{(z)}$ are with (him) in the same city ${ }^{(\text {aa) }}{ }^{(10)}$ Joyful is the man who does $<$ little ${ }^{(b b)}$, while his princes are miserable ${ }^{(c c)}$ ?"

\section{Outer side:}

${ }^{(1)}$ (It is) Shepsi ${ }^{\text {(dd) }}$ who speaks to his mother Iy:

(2) "This is a reminder (ee) of the fact that you said ${ }^{(\mathrm{ff})}$ to this your son: 'Bring me quails for me that I might eat ${ }^{(\mathrm{gg})}$ them', and this your son brought ${ }^{(\text {hh) }}$ to you ${ }^{(3)}$ seven quails for you and you ate them. Am I to be injured in your presence ${ }^{(i i)}$, being (your) children ${ }^{(j)}$ blind ${ }^{(\mathrm{kk})}$ towards this your son who is suffering? (1) (4) Who then shall pour out water for you? ${ }^{(\mathrm{mm})}$ Might you judge me together with Sobekhotep ${ }^{(\mathrm{nn})}$. I brought him back from another town, and placed (him) in his town, ${ }^{(5)}$ among his male and female dead, and gave him burial cloth ${ }^{\left({ }^{\circ o}\right)}$. Why then is he ${ }^{(\mathrm{pp})}$ acting against this your son, without I having ${ }^{(\mathrm{qq})}$ said and done (anything) very wrongfully ${ }^{(\mathrm{rr})}{ }^{(6)}$. Evil-doing is painful for the gods!"

\section{Philological notes}

(a) sppsis. The name Shepsis [sic] is not attested, though it can be either a graphic variant of the name Shepsi, which is, instead, frequently attested in the Old Kingdom, Ranke, PN, 326, 15, or a spelling mistake for the writing of Shepsi, with the inversion of $l$ and $s$. The same name is spelt in the traditional way, $\check{s} p s i$, in the outer letter (see below, n. dd).

(b) 'Tinh-n-mwt. This name is not known elsewhere, cf. Ranke, PN, 10, 9.

(c) $t n w-r\}$. The expression $t n w-r\}$, "oral reminder", "memorandum", "explanation" (Hannig, Lexica 4, 1451; Wb V, 380, 1; Meeks, AnLex 2, 78.4689; for First Intermediate Period-Middle Kingdom usage, see Vernus 1996, 170-172); it is frequently used in the letters to the dead (four times, $\alpha-\delta$ ), and introduces a narration of facts, see Donnat 2010, 65-66; Donnat 2009, 67-68, n. 42, and 80-81. The major aspect of the $t n w-r\}$ formula in the letters to the dead, is the fact that it introduces events that happened while the deceased was still alive: $\alpha$ ) Letter Cai- ro JE 25975 (see doc. no. 1): Irti reminded Seankhenptah, her deceased husband and addressee of the letter, of the dialogue between him and Behezti's messenger about the question of inheritance (see new interpretation in Miniaci 2014b); hence, the conversation must have happened when Seankhenptah was still alive (Willems 1991, 183-191; Miniaci 2014a, 41-44); $\beta$ ) Letter Chicago OIM 13945 (doc. no. 5): an anonymous person reminds the deceased (anonymous) of a conversation he had had in the past with one of his parents, Idu. Although the conversation could have happened in/between two different worlds (the hereafter and earth), the presence of the sender as the witness links the whole episode at the time when the deceased was still alive; y) Letter Qau UC16163: Shepsi addressed the first letter -inner side- to his father, reminding him of an unclear episode (see below, n. e); 8) Letter Qau UC16163: in the second letter on the outer side of the bowl, Shepsi reminded his mother of the episode when he brought seven quails at her request. The linguistic aspect of the verb, $d d=k$ (see below, $n$. ff), seems to emphasise that it refers to a specific event more than to a habit. Consequently, it sets the scene again in the life span of the individuals. However, the context is ambiguous, and the episode of seven quails could also refer to a mother's request from the netherworld, asking for her funerary meal. Moreover, two other letters, although not introduced by the $t n w-r$ formula, open with anecdotes which happened while the deceased was still alive, see letter to Ankhiry in Leiden (doc. no.16), and possibly, with some difficulties in interpretation, letter of Butehamun to Ikhtay from Deir el-Medina (doc. no. 17).

(d) $\check{s}\}=k$. Gardiner and Sethe emended the word $\check{s}^{3}=k$ with $\check{s}\langle<s>=k$, "your travel", from the verb $\breve{s} 3 s$, "travel, go”, see Hannig, Lexica 4, 1281; Wb IV, 412, 3-7, Donnat 2009, 81-82. However, as Gardiner and Sethe pointed out, other texts include the variant of $\breve{s} 3 s$ without $s$, see Gardiner, Sethe 1928, 17 (II, 2).

(e) ith. The reading of the group is debated. The signs $i$ and $t$, and the "house" determinative are beyond doubt, as pointed out also by Gardiner, Sethe 1928, 17 (II, 2). Indeed, the uncertain reading of the vertical stroke following the $\vec{i}$ and $t$ signs has created some difficulties with the interpretation. Due to the funerary setting, some scholars (e.g. Farout 2004) have tended to emend the group with the word

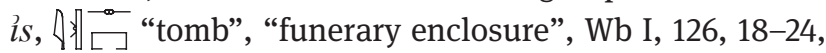
although Gardiner and Sethe already warned against such an unconvincing alternative, mainly due to the undeniable presence of the sign $t$. The vertical stroke could be interpreted as the sign $h$, composing the word $i t h, \ell_{\triangle} \& \leftleftarrows \square$, interpreted, at the time Gardiner and Sethe were working on the letters, as "prison", probably based on Griffith 1889, pl. 11, line 18. However, more recently published evidence 
indicates that the meaning of ith is "fortress", Faulkner, Dictionary, 34; "Befestigung" "castle, fortified building", Wb I, 148, 24-25; "Fort, Kastell, befestige Anlage” Hannig Lexica 4, 237. The word ith is attested in a fragment of the biographical inscription of Mereri, from Dendera ( $q$ d. $n=(i)$ ith, "I built a fortress", Fischer 1968, 140), in the stela of Maaty, in the Brooklyn Museum (imy-r) ith, "overseer of the fortress", Fischer 1968, 140), and in the biographical inscription of Ankhtifi at Moalla, employed three times to indicate the fortresses of Armant ("going downstream to the fortresses"; "the fortresses of Armant in the "Hill of Semekhsen"; "in order to demolish the fortress<es $>$ with the valour of the troupe of Hefat", Vandier 1950, 198-199 -inscription no.6). In all the attestations, the word ith as "fortress" is always followed by the determinative of a baker's rake, ₹ (Gardiner, Grammar, Sign-list U31), single or doubled, while it is missing in Shepsi's letter. To reinforce the interpretation of the group of signs as the term $i t h$, fortress, one notes that further down the text of the letter Shepsi refers again to this place (see below, n. l).

(f) $s n s 3 h t p w$ alternate reading (?)】 $\Rightarrow$ $<s b k>h t p(w)$, see Ranke, PN, 305, 6. The group of signs reads, following the interpretation of Gardiner and Sethe, sn s3 htpw, "Hetepu, son of Sen". This person remains obscure throughout the whole letter; his role could be similar to that one of Nuajef (see below, n. i), as the witness of an episode that happened while the deceased was still alive. However, Sylvie Donnat, following an initial suggestion of Gardiner and Sethe, that was later dismissed, has proposed to emend the hieratic signs to " $s n=(i)<s b k>h t p$ ", "my brother Sobekhotep", Donnat 2010, 57; Donnat 2009, 82, n. 123. The proposed emendation represents a lectio difficilior, since the difference in hieratic calligraphy between the signs $s 3$ and $s b k$ is evident, indicated by the omission of an oblique stroke in the $s$ 3 sign, _ ; (Goedicke 1988, 16b, sign 39/216 -Funerary-) which is present, but not always in the $s b k$ sign, see Goedicke 1988, 18b, sign 5/242 (Funerary), cf. signs under Heqanachte in Goedicke's list, e.g. $\boldsymbol{\sim}$. Moreover, the word $s n$, with the meaning of "brother", should have been written with the appropriate determinative. Nevertheless, the interpretation recently proposed by Donnat has the advantage of connecting the inner and outer letters more explicitly and providing a more coherent picture, where Shepsi together with his father would have gone to visit his brother Sobekhotep in a fortress far from home (see above, n. e), where he eventually died, and from where Shepsi brought back his body (see below, n. 1).

(g) $m$ in $=$ (i) $n=k$. An analogy can be made with the outer letter of the Qau bowl, column 2, $m$ inn=(i) $n=\underline{t}$, "when I brought to you" (see below, n. hh), the construc- tion $\min =$ (i) $n=k$, "when I brought to you", is preferred to m in. $n=k$ "when you brought". The perfective aspect of the verb, $s \underline{d} m=f$, denotes here a single episode rather than a repetitive act, contra Donnat 2014, 36, n. 40. Other similar subsidiary sentences in the letter to the dead, introduced by the particle $m$ and following the $t n w-r$ ? formula might use both $s \underline{d} m=f$ and $s \underline{d} m . n=f$ tenses, see Gardiner, Sethe 1928, 14.

(h) $s^{3}=k \mathrm{im}$. Literally "this your son”, but Dorota Čzerwik $(1999,62)$ prefers to translate the expression with an emphatic first person pronoun, "I, me", see also Donnat 2014, 118-119. This expression is often used in letters to the dead, see Donnat 2014, 56, n.18. A similar expression can be seen in ordinary correspondence, Edel 1992, 80-81. However, here I prefer to maintain "this your son", mainly to avoid complication in translation of two very difficult points, see below, nn. $\mathrm{k}$ and kk.

(i) $N-w^{3}=f$. Nuaef; this name is not attested elsewhere. In the New Kingdom ( $18^{\text {th }}$ dynasty) a similar name $n-t$ - $-w$ 3$r=f($ ?) is attested, Ranke, PN, 169, 3.

(j) iw $n=(i) s[n . w y]$. Gardiner and Sethe restored the text at this point as $s[n . w y]$, "two", to be interpreted as "you two", $(1928,17)$. However, in the following sentence, the subject of the verbs is singular hms $w n m=k$, "sit and you eat", as noted by Donnat 2014, 38, n. c. Hence, if the substitution of Hetepu with Sobekhotep is correct, the whole sentence could be re-interpreted as, iw $n=(i)$ $s[n=(i)]$ "Welcome to me, my brother", where it is Sobekhotep who greets his brother Shepsi who has arrived to visit him together with their father and Nuaef. For the welcoming formula, see Oréal 2008, 352.

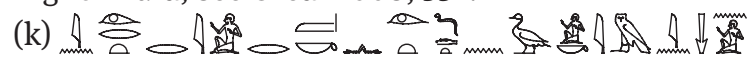

in $i r r=t(w) \quad r=(i) \quad r \quad g s=k n j i r . t(w) / d \operatorname{dd} t(w) n s^{3}=k i m$ in $s n=i$.

The meaning of $i r r$ in $i r r . t(w)$ as "to do/commit (something dangerous)" is attested elsewhere in letters to the dead, see letter to Nefersekhi from $\mathrm{Hu}$ (doc. no. 7); letter of Dedi to Intef from Saqqara (doc. no. 10), Gardiner, Sethe 1928, 17, n. II.4. The clauses (main and subordinate or parenthetic) have always been interpreted as an attempt by Shepsi to defend himself because of some offence he might have committed against his brother Sobekhotep; thus, the passage has been translated in various ways:

1) "Am I being injured in thy presence, without this son having done or said aught, by my brother?", Gardiner, Sethe 1928, 4;

2) "Is it in your presence that I am being injured by my brother even though there is nothing that I, your son, did or said?”, Wente 1990, 212; 
3) "Est-ce en ta presence qu'on agit contre moi - sans qu'une chose ait été dite ou faite par ton fils-que-jesuis -, à cause de mon frère”, Donnat 2014, 36;

4) “Est-ce que c'est en ta presence qu'on peut se permettre d'agir contre moi -alors que ton humble fils n'a rien fait ni dit (de mal) - et par mon frère (en plus)”, Farout 2004, 47.

In these cases, the first clause is in irr.t(w) $r=$ (i) $r g s=k \ldots$ in $s n=i$, with in marking the delayed agent of the passive verb $\operatorname{irr} . t(w)$. The negative clause, $n \operatorname{ir} . t(w) / d d . t(w) n s j=k$ $\mathrm{im}$, is interpreted as a parenthetic. Such a construction requires a much-delayed agentive phrase, rare but attested, see Edel, 1955/1964, 1073.

In all the translations above, Shepsi is interpreted as the performer (subject) of the actions of having said and done (interpreted as ir.t.n and dd.t.n) and his brother as the agent of the offence-irr.t(w)-. The subordinate clause, then, is interpreted as a parenthetic non-existence clause: $n$ ir.t.n/dd.t.n s $3=k i m$, "without your son having said and done (anything)". The guidance for the construction of this subordinate clause is driven from a parallel negative

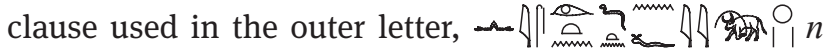
is ir.t. $n=(i) / d$ d.t. $n=(i)$ nfy sp 2, "without having your son said and done (anything) very wrongfully" (see below, $n$. rr). The structure is mirroring: negative particle $n+$ perfect relative form of verbs $i r(i)$ and $\underline{d} d+$ subject $-s j=k i \mathrm{~m} /$ (i)-. Although the two clauses seem accurately to follow the same structure, there is a substantial difference: in the outer letter, the ending $n$ of the verbs $\underline{d} d$. $t$ and $i r . t$ is repeated under each verb, while in the inner letter there is only one $n$ after the verbs $i$.t $t$ and $d$ d.t. In my view, this is a substantial clue to assert that the two sentences do not mirror the same construction.

However, there is another parallel construction used in column 3 of the outer letter, which might help in providing an alternative interpretation of the text:

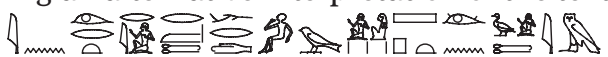
in irr.t(w) $r=(i) r$ gs=t $\underline{h} r d . w=<k>\check{s} p\{t\} n s\}=\underline{i m}$,

"Am I injured in your presence, being <your> children blind towards your son?" (for the interpretation of this sentence see below, n. kk). In this case, the person who wrote the two texts (inner and outer letters) clearly assembled the two sentences using the same construction. For convenience, I label the sentence in the inner part of the bowl (letter to the father) as sentence I, and that on the outer part of the bowl (letter to the mother) as sentence II. Both sentences open with a question (interrogative clause, introduced by the particle $i n$ ), in irr.t(w) $r=i r$ $g_{s}=k / \underline{t}$, where only the suffix pronoun changes according to the gender of the addressee, mother or father $(=k /=t)$. Both interrogative sentences are followed by subsidiary sentences (sentence I is introduced by a negative particle (n); sentence II is a stative construction, see below, n. kk), both ending with $n s j=k / \underline{t} i m$, which corresponds, in both cases, to the indirect object, the person towards whom the action is performed.

Table 04: A comparative summary between sentence I and sentence II. In bold grammatical and structural variations.

\begin{tabular}{|c|c|c|c|c|c|}
\hline $\begin{array}{l}\text { Sen- } \\
\text { tence }\end{array}$ & $\begin{array}{l}\text { Interrogative } \\
\text { clause }\end{array}$ & $\begin{array}{l}\text { Subject/ } \\
\text { Agent }\end{array}$ & $\begin{array}{l}\text { Verbal predicate } \\
\text { of the interroga- } \\
\text { tive clause }\end{array}$ & $\begin{array}{l}\text { Indirect } \\
\text { object }\end{array}$ & $\begin{array}{l}\text { Subject/ } \\
\text { Agent }\end{array}$ \\
\hline I & $\begin{array}{l}\text { in irrtt(w) } r=i \\
r g_{S}=k\end{array}$ & & nj ir.t(w)/dd.t(w) & $\begin{array}{l}n s 3=k \\
l m\end{array}$ & in $s n=i$ \\
\hline II & $\begin{array}{l}\text { in irr.t(w) } r=i \\
r g_{S}=t\end{array}$ & $h r d . w$ & $\check{s} p\{t\}$ & $\begin{array}{l}n s^{3}=\underline{t} \\
i m\end{array}$ & \\
\hline
\end{tabular}

At this point, I see the reason for a different interpretation of the subsidiary clause in sentence I. The verbal predicate can be interpreted as a passive perfective form of the verbs $i r(i)$ and $\underline{d} d$, as a $s \underline{d} d m . t w=f$ form, Allen 2000, 264, Brose 2014, 251-260, and Vernus 1986, 380, followed by the agent, in sn.i, at the end of the clause: in irr.t(w) $r=(i)$ $r g s=k$ "Am I to be injured in your presence", $n j$ ir.t $(w)$ ) dd.t(w) $n$ s $3=k$ im in $s n=i$, "without (anything) being acted for/spoken for your son by my brother". Such a construction has the benefit to tie the agentive phrase in $s n=i$ to the negated verbs $n$ ir.t and $n \underline{d} d$.t instead of a much-delayed construction linking the agentive phrase with the initial interrogative clause, and to explain the single $n$ (in this case a preposition, as dativus commodi, "for/für", cf. Brose 2014, $\S 107$, no. 25, and not an ending of the verbal forms) after the verbs $n$ ir.t and $n \underline{d} d$.t. Following the proposed interpretation of the sentence, the whole meaning of the letter completely changes, and rather than attempting to apologise himself, Shepsi complains that his brother is not supporting him from the hereafter.

5) "Am I to be injured in your presence, without (anything) being acted for/spoken for this your son by my brother".

David Silverman has proposed an alternative reading for this sentence, without taking ir.t and $d d . t$ to be a parallel grammatical construction, but similarly treating $i n s n=i$ as linked to $n i r . t(w)$ and interpreting dd.t.n $^{\prime} s^{\prime}=k i m$ as a perfect relative form "that which your son said", the "subject" of the negative sentence. 
6) "It is in your presence that evil is done against me, while that which your son said was done by my brother?”, Silverman 1980, 21.

Other alternative constructions have been proposed by Günter Roeder and Sylvie Donnat, who interpreted in $s n=?$ as a separate sentence, and by Čerwik, who sees $i n s n=\imath$ as the beginning of a new sentence:

7) "Was wird gegen mich getan an deiner Seite? Nicht ist (etwas) getan worden oder gesagt worden für deinen Sohn da. Mein Bruder ist es, den ich bestattet habe und den ich in das Grab gebracht habe [...]", Roeder 1961, 276;

8) "Is it in your presence that one acts against me? Even if your son who I am said or did nothing wrong? Is it my brother?", Donnat 2010, 56;

9) "Is it in your presence that evil is done against me, while I, your son, haven't done or said anything?”, Čerwik 1999, 62.

Andréas Stauder recently proposed to see $i n s n=i$ as an emphatic agent in the "rhematic tail of the sentence" tied to the following sentence, qrs.n=(i) $s w$ :

10) "Is there acting against me next to you - even though there is nothing that your son did or said - by my brother, whom I buried?”, Stauder 2014, 173.

(l) $i t[h]$ (?). Gardiner and Sethe stress the fact that the word cannot be interpreted as ith, although they confess they were not able to read clearly the signs at this point $(1928,17)$. Indeed, the arrangement of signs could correspond to the lemma in the second column, ith. Gardiner and Sethe interpreted the last hieratic sign as the knotted belt, $\bowtie$, but it could also indeed be the baker's rack, $\longleftarrow$ (cf. Goedicke 1988, 40b, sign U31, Funerary). It is more difficult to explain the $t$ sign before the determinative. If this word is read as "fortress", the sense of the letter would be more coherent: Shepsi went to visit his brother Sobekhotep in a fortress (see above, n. e), and brought back his body from there to his native town.

(m) $s k$ ( $h q 3 . t) 30 i t-\check{s} m^{c} r=f$. The meaning of sentence is clear; it cost Shepsi 30 gallons of Upper Egyptian barley for the transportation of the body of his deceased brother from the place where he was to his hometown cemetery.

(n) $d 3 i w$, var. of $d i w$, "loin-cloth", Faulkner, Dictionary, 309; "Leinenstoffballen; Stoffballen”, Wb V, 417, 3; “Schurz, Kilt”, Hannig, Lexica 4, 1462 \{38511\}. Cf. also Posener-Kriéger 1976, 359.

(o) mnwi. Gardiner and Sethe interpreted this term as $m n w i, \underset{m}{M}$, mace. The word $m n w$, followed by the rope determinative (Gardiner, Grammar, Sign-list V1) might be better translated as "string", Wb II, 72, 8. The last determinative read by Gardiner and Sethe as $t m$, $(1928,18)$, could instead be the garment sign, $\square$ (Gardiner, Grammar, Sign-list N18), in the word $m n w i$, "Maß (für Kleiderstoffe)", Hannig, Lexica 4, 528 \{12845\}. The word $m n w i$ is attested in the administrative papyri from the temple of Neferirkare at Abusir, recorded amongst other cloth accounted in occasional deliveries from Setibre's warehouse: Compte 51, $2 b$ - étoffe szf: 10 - étoffe nfrw: 20 pièce de 30 en largeur 3: 4 (fait = delivered) $-m n w$ de fil [nwt]: 5, see Posener-Kriéger 1976, 370, 377, 673.

(p) šns. The reading of the signs is not clear, as stressed by Gardiner and Sethe $(1928,18)$. However, Gunn emended the group signs in $\check{s} n \underline{d} . t$, "one kilt”, translating them as "flax for a kilt", but such a solution remains open to grammatical objections as already admitted by Gunn himself $(1930,151)$. Donnat interprets this word as $\check{s} n w$ and connects it to the previous lemma $\left(m h^{c} w\right)$, preferring $m h w$ šnw "un ballot de lin" $(2014,36)$. As evident from the Compte 51, 2a of the Abusir Papyrus, the word $\check{s} n s$ in the expression $\check{s} n s h m 3 t$, "šns of salt", seems to refer to a shape, intended as unit of measurement (Posener-Kriéger 1976, 370, 376-377, 683, see discussion in Janssen 1975, 440-441), more than to the "bread loaf" itself, see Hannig, Lexica 4, 1311 \{33277\}. Ancient Egyptian employed volume measurement following the noun, see for example $m h^{c} w$ šs $r w$, "sheaves of flax" (Allen 2002, 63, pl. 40, account $\left.\mathrm{V}^{\mathrm{x}}, 7-8\right)$. For other readings of this unclear group of signs, see Gunn 1930, 151.

(q) $m h^{c} w$, "flax", Faulkner, Dictionary, 114; "Flachs, Kulturlein (Linum usitatissimum)”, Hannig, Lexica 4, 551 \{13567\}. The word $m h y$ is in the Old Kingdom attested as $m h^{c} w$, for the spelling cf. Allen 2002, pl. 40, $\mathrm{V}^{\mathrm{r}} 7-8$.

(r) $m h t$, type of cup, Hannig, Lexica 4, 551 \{13567\}; Faulkner, Dictionary, 113.

(s) $i r . n=f$. At first sight, the subject of this sentence seems to refer to Sobekhotep, the brother of Shepsi. However, I suspect that the subject here suddenly changes and the sender of the letter is referring, with the suffix pronoun, $f$, to Henu, mentioned further in the text, in the column 8. However, even if he refers to his brother Sobekhotep, the sentence could be interpreted: Shepsi is stressing the fact that by depriving him of his protection from the hereafter, his brother is acting unjustly against him.

(t) $n f y$ sp 2. The expression $s p$-sn, "two times" is referred to the preceding adverb, $n f y$, and it has the effect of producing a repetition of the word, stressing its comparative and superlative value, see Gardiner, Grammar, 206, $\S 207$.

(u) The suffix pronoun, $k$, is referred by Shepsi to his father. 
(v) The name Sher is not attested elsewhere.

(w) The dependent pronoun, $s w$, probably refers to Sobekhotep himself, who is dead like his father, as pointed out by Gardiner and Sethe $(1928,18)$. Henu seems to be directly involved in the property dispute with Shepsi, hence he must not be in the same place as Shepsi's father. It could be possible, albeit with major difficulties of contextualisation, to presume that the pronoun refers to Henu's father, Sher.

(x) $m$ niw.t $w^{c} . t$, lit. "in a sole city". This expression occurs in another letter to the dead, written to Meru from Naga el-Deir N3737 (doc. no. 4). In CT, the expression a niw.t th often appears, pointing to a city or a place in the hereafter, Szpakowska 2003, 27, nn. 91-93.

(y) ir $n=k$ ir.t $w d^{c}-m d w$, "Make a judgement". The ir $n=k$ form before infinitive (ir.t) is used as periphrasis for the imperative. The idea that a deceased can "make a judgment" from the hereafter in support of the familiar occurs in other letters to the dead, see the letter to Nefersekhi from $\mathrm{Hu}$ (doc. no.7), line 4 ( $w p . t=$ judgement); letter to Mereri in the Louvre (doc. no. 9), line $18(s m i+m=$ report against somebody); letter to Ankhiry in Leiden (doc. no. 16), line 38 (wp.t). On the terms $w p i$ and $w d^{c}-m d w$, see Grieshammer 1970, 149-152. In the letter of Seankhenptah from Saqqara (see doc. no.1), the deceased is expected to be supported by other familiars, "raise yourself up against them, together with your father, your brothers, and your friends", lines 10-11. In the letter of Qau, with this expression, Shepsi asks his father to join forces with his brother, Sobekhotep, from the hereafter.

(z) $s \check{s} . w=k$. Lit. "your scribes", but in letters this expression is used to indicate the addressee of the letter, Donnat 2014, 118. Since the transcription of the word is quite doubtful, Gunn suggested the interpretation "relatives of some sort" $(1930,151)$.

(aa) $m$ niw.t $w^{c} . t$, lit. "in a sole city", see above, $\mathrm{n} . \mathrm{x}$.

(bb) $\langle n d s>$. The lemma $n s$ is not known, but the sign that Gardiner and Sethe interpreted as the biliteral sign, (Gardiner, Grammar, Sign-list F20) T, could indeed be $\left.d{ }^{2}\right\}, \succ$, cf. Goedicke 1988, 19a, sign 10/250 (Elephantine). In the facsimile produced by Gardiner and Sethe, the stroke interpreted as the bent line of the tongue sign could be with some difficulties the ligature of the $n$ (cf. column 4) $\sqrt{2}$, or it must be emended. With such a correction the term can be read $n d s$, , 2 , Wb II, 384, 8-13; Faulkner, Dictionary, 145. The meaning of $n d s$, "little, small”, makes sense of the last sentence and the whole letter: "Joyful is the man who does <little>, while his princes are miserable?"; the men who are inactive and produce little should not be joyful, while the princes who produce plenty should not be considered miserable. The sentence can be interpreted as an exhortation, through a proverbial and rhetoric sentence, to his brother in order to convince him to act in his support. As Gardiner and Sethe pointed out, the letter would possibly have ended with a closing-sentence, a proverb, on analogy with the outer letter (see column 6), or a greeting, like other letters to the dead.

(cc) miserable.

(dd) špsi. The name Shepsi is here written as expected, cf. above n. a.

(ee) See above n. c.

(ff) $\underline{d} d$.t. . The $\underline{d} d=f$ form used here, in place of the expected perfect form $\underline{d} d . n=k$, is a perfective form, which denotes an action that happened in the past, and refers to a specific event more than to a custom or habit, Gardiner, Sethe 1928, 19; cf. Allen 2000, 264.

(gg) $w n m=$ (i) $s .<t>$. Gardiner and Sethe emended the pronoun in this part based on an analogy with the same word, $s t$, used in the next column, wnm $=\underline{t}$ s.t, Gardiner, Sethe 1928, 19.

(hh) $i n n=(i) n=t$. I prefer to use the performative of the verb $i n n=(i) n=\underline{t}$ rather than a past form, $i n . n=(i) n=t$, since the $s \underline{d} m . n=f$ form is not attested in the letters to the dead after the $t n w-r$ ' sentence (see above, $\mathrm{n}$. g).

(ii) Same expression as before, see above $n . k$.

(ji) $h r d . w$. The word $\underline{h} r d . w$ could also be interpreted in a metaphoric way as "dependants" of a house, instead of "children", see Donnat 2010, 56, n. 19 and n. 58, Donnat 2014, 39. In this case, I prefer to preserve the meaning "children" and interpret this passage in parallel with the first letter inscribed in the inner part of the bowl (see above, n. k). In the inner letter, after the reminder of a past action, Shepsi's complaint against the inaction of his brother Sobekhotep is expressed to his detriment; in the outer letter Shepsi could again complain against inaction of his brother Sobekhotep. The word hrd.w could be addressed to the mother's children, and hence directly involve Sobekhotep as one of Iy's sons. In this case, an emendation of the text is possible, though not necessary, adding a suffix pronoun to the word children, $\underline{h} r d . w=\langle k\rangle$, "your children" (see below $\mathrm{n}$. jj).

(kk) $\check{s} p t$. According to Gardiner and Sethe the verb seemed "as though it came from the stem $\check{s} p$ 'be blind', but the $t$ admits no grammatical explanation, and it seems evident that $\square_{\square}$ of $\check{s} p t$ 'being discontent' is meant, the determinative being wrongly borrowed from the other stem”, Gardiner, Sethe 1928, 19. Gardiner and Sethe, then, propose to emend the determinative of the painted eye, ar (Gardiner, Grammar, Sign-list D5) with the sign 8 (Gardiner, Grammar, Sign-list K7), preferring the term $\check{s} p t$, "being discontent", Wb IV, 453, 10-16. By interpreting $\check{s} p t$ as a stative of the verb "being discontent", the sense of 
the sentence remains slightly obscure, "Am I being injured in your presence, the children/dependants being discontent with this your son?”, cf. Gardiner, Sethe 1928, 4. The meaning of the sentence could be that the children or dependants of Shepsi will be discontent if his deceased mother does not protect him, and this could explain also the following sentence, "Who then shall pour out water for you?", emphasizing the fact that if the house of Shepsi should fall into disgrace, no one would be there to take care of the funerary ritual for his mother. Other scholars prefer similar translations: "Is it in your presence that one acts against me? My dependants are upset because your son who I am is suffering”, Donnat 2010, 56. I propose here an alternative translation; since an emendation is needed, I suggest emending the $t, \breve{s} p\{t\}$, paying greater heed to the painted eye determinative, which could instead reveal the real intention of the writer of the letter. The construction would remain unchanged, subject + stative, "(your) children being blind towards (?) your son”. The clause in this case would be addressed to Iy's children, including Sobekhotep, who are in the hereafter and blind to Shepsi's plight. Although the general meaning of the letter would benefit from such an arrangement, grammatical difficulties remain in explaining the use of the preposition $n$ after the verb $\check{s} p$, which is not elsewhere attested, see Wb IV, 443, 1-11.

(ll) $m r$ "seelisch schlimm sein", Hannig, Lexica 4, 539 \{13188\}; "painful”, Faulkner, Dictionary, 110. The word here has to be interpreted as appositional to the subject $s^{3}=k i m$. For $s^{3}=k i m$ as an emphatic pronoun of first person singular, see above, $\mathrm{n}$. $\mathrm{h}$.

$(\mathrm{mm})$ The sentence need not necessarily be interpreted as a threat, i.e. that the son would not pour water for his deceased mother should she fail to provide help from the hereafter; it could simply imply that if the son falls into disgrace, he would be unable to afford libations for his mother.

(nn) $w p=\underline{t} w(i) h n^{c} s b k h t p$. The expression $w p$ means "to judge". The expression "judge sb. together/against

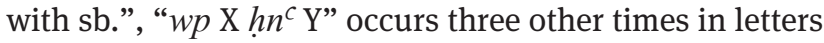
to the dead, letter to Ankhiry in Leiden (doc. no.16), lines 7 and 38, letter to Nefersekhi from Hu (doc. no. 7), column 5. In the Leiden papyrus the context is quite ambiguous, "shall be decided between you and me (by means of) this writing" (line 7), "It shall be decided between you and me" (line 38); while in the Hu bowl a derogatory nuance is explicit "Make a sentence against all who make (me) suffer" (columns 4-5). By analogy with the inner letter, columns 8, I prefer to interpret the preposition $h n^{c}$ as stressing the fact that his mother is called to make a judgment together with his brother and not "between" Shepsi and his broth- er. For $w p$, see Faulkner, Dictionary, 59; Wb I, 299, 5-6 (see above $n$. y).

(oo) The whole episode of the funeral of Sobekhotep is repeated here with minor details. The determinative of hbs, cloth, might be "⿱⿲㇒丨丶㇒弔 Goedicke 1988, 36a, sign 28/430 (Hatnub).

(pp) The pronoun "he" quite certainly refers to Sobekhotep, who might be feel outraged by Shepsi and for this reason does not support him from the hereafter.

(qq) The use of the first pronoun, $i$, seems left undefined but it is implied in the meaning of the clause.

(rr) $i r=f r$ s $j=\underline{t} i m h r$-iš.t $n$-is ir.t. $n=(i) / d$ dd.t. $n=(i) n f y$ $s p 2$, "why then is he acting against this your son, without I having done and said (anything) very wrongful". The sentence might mirror a logical structure already used before, see above, $n$. k. The verbal form used here effectively corresponds to the perfect of a relative form, $d d t . n=f$, see Allen 2000, 348, setting the action in the past, with an "accompli non-extensif" aspect of the verb (Vernus, 1986 381). For the expression $n$-is, see Gilula 1969, 216-217.

\section{The content of the letter}

Due to the complexity of the letter and the events described in it, it is worth summarising the contents of the letter in the light of the archaeological information and the new reading proposed here. Firstly, it is worthwhile listing here the individuals involved in the events:

Shepsi: sender of the two letters;

Inkhenmut: deceased father of Shepsi (addressee of the inner letter);

Iy: deceased mother of Shepsi (addressee of the outer letter);

Sobekhotep: deceased brother of Shepsi;

Nuaef: a person present, as a witness (?), at the meal of Shepsi, his father and Sobekhotep;

Henu: son of Sher, the person who threatens to take possession of Shepsi's property.

In the inner letter, Shepsi speaks to his deceased father, Inkhenmut, reminding him of an event that happened while his father was still alive. Although the location of the episode is far from clear, the mention of "journey" and "fortress" seems to set the whole scene outside the hometown of the family, probably at the fortress or the enclosure where Sobekhotep was carrying out his duties in life. The episode refers to a meal between Inkhenmut, the two brothers, Sobekhotep and Shepsi, and another person called Nuaef, whose role is not clear, but probably serves as a witness to the event (1-3). 
The main focus of the letter is expressed by a rhetorical question: should the indolence of his deceased brother towards Shepsi, who is not supported by him in the hereafter, pass in silence? In the main part of the letter, Shepsi refers in detail to the efforts he took over the funeral of one of his brothers (4), whose name is never explicitly quoted in the account of the funeral. However, due to the strict analogies with the second letter, where the burial of his brother Sobekhotep is mentioned, it is possible to assume that Shepsi is referring to Sobekhotep's burial also in the first letter. In both letters, Shepsi reminds his deceased parents that he brought the body of his deceased brother from a distant place to his hometown cemetery and that he took care, both practically and financially, to provide him with a proper funeral (5-6).

The motivation driving Shepsi to write the letter is quoted only at the end of the text, where Shepsi informs his father that Henu, son of Sher, is trying to take possession of his property (6-8). Henu is the real cause of Shepsi's complaint. Therefore, Shepsi asks his father to make a judgment in the hereafter together with his brother. The letter closes with a proverbial sentence, the translation of which is doubtful (9-10); probably it is a rhetorical question about the uneven reward between negligent people and the princes who also take care of others. Probably this sentence refers directly to Sobekhotep, from whom Shepsi would expect major support from the hereafter.

In the outer letter, Shepsi speaks to his mother, Iy, recalling an event that happened in the past when he brought to her seven quails at her request (1-3). Also, the focus in this letter is upon the funeral of his brother: Shepsi refers, though more concisely, to the burial of his brother, here explicitly named, Sobekhotep. Here, Shepsi asks his mother to make a judgment from the hereafter together with his brother. (4-5). Shepsi closes the letter again with a proverbial sentence, stressing that gods abhor injustice, as Shepsi is suffering an undeserved injustice (6).

\section{Reuniting philology and archaeology}

Starting from the point of view of an external observer (etic), we have seen in the archaeological evidence that a single male body lay in the funerary chamber, a fact that contrasts with the two addressees of the letters. But from what we "heard" on philological grounds (emic), the focus of the two letters has moved from Shepsi's parents to Shepsi's brother, Sobekhotep, who is the prime element in both texts. Combining the etic and the emic, a new overall perspective seems to support the idea that the deceased found together with the bowl in Qau tomb 7695 is Sobekhotep himself.

In past interpretations of the letters, Sobekhotep was seen as the dead who threatens Shepsi from the hereafter, while Shepsi was trying to rid himself of the danger coming from his brother. The new philological reading here proposed sheds new light on Sobekhotep, switching his role from the dangerous to simply negligent dead. In both letters, the focus is on the event of Sobekhotep's burial, repeated as the main matter and located exactly at the centre of the texts. Hence, the role of Sobekhotep is central to both letters, while his parents simply represent the audience but not the real recipients. Shepsi's parents are both asked to make a judgment together with Sobekhotep in the hereafter in support of Shepsi's dispute. The actual reason for Shepsi's discomfort and the compelling motivation for writing the letter is not Sobekhotep himself but the dispute with Henu about Shepsi's property. The complaints of Shepsi are not directed against Sobekhotep, but about his lack of support from the hereafter. The particular emphasis of the episode of the funeral/burial of Sobekhotep reveals that Shepsi expects a reward, which does not arrive, from his brother. The fact that Sobekhotep does not support Shepsi in the afterlife is explicitly stated "without (there) being anything acted for/done for your son by my brother", "being your children blind towards your son". Sobekhotep is the last person to have died in Shepsi's family, as in many points evident in the two letters. The reason why Shepsi decided to address the letters to his parents and not to Sobekhotep may be due to the length of time between the death of the brother and his burial (it cannot have been immediate, because there was at least a delay for the transportation of the body). Shepsi's dispute with Henu (whenever it arose) continued after the death of Sobekhotep, hence he decided to include the bowl in the burial of Sobekhotep, and address the letter to his parents in order to force Sobekhotep to help him from the afterlife, since he was not spontaneously providing him with any support from thereafter.

Acknowledgement: I wish to thank Stephen Quirke for revising this article and Mark Collier and Ilona Regulski for comments on grammatical points. I owe a debt of gratitude to Sylvie Donnat, who provided me with many of her articles, and to Marilina Betrò, whoinspired this subject. I wish also to thank also Elena Tiribilli for editing hieroglyphic inscriptions and Paul Whelan for revising my English. 


\section{Bibliography}

Allen, J.P., 2000, Middle Egyptian: an introduction to the language and culture of hieroglyphs, Cambridge.

Allen, J.P., 2002, The Heqanakht Papyri, PMMA 27.

Anonymous, 1928, “Missives aux morts”, CdE 7, 112-122.

Blench, R., M. Spriggs (eds.) 1999, Archaeology and Language III. Artefacts, Languages and Texts, London-New York.

Brier, B., 1980, Ancient Egyptian Magic, New York.

Brose, M., 2014, Grammatik der dokumentarischen Texte des Mittleren Reiches, LingAeg 13.

Brunton, G., 1927, Qau and Badari, Vol. I, London.

Brunton, G., 1928, Qau and Badari, Vol. II, London.

Černý, J., 1973, A community of workmen at Thebes in the Ramesside Period, Le Caire.

Černý, J., A.H. Gardiner, 1957, Hieratic Ostraca, Vol. I, Oxford.

Čerwik, D., 1999, “Some Remarks on the Letters to the Dead from the First Intermediate Period”, GM 173, 61-68.

Donker van Heel, K., J. Golverdingen, 2003, An Abnormal Hieratic Reading Book Containing Texts from the British Museum (London), the Brooklyn Museum (New York), the Egyptian Museum (Cairo), the Louvre (Paris), the Museo Egizio (Turin), the Nationalbibliothek (Vienna), Queen's College (Oxford) and the Rijksmuseum van Oudheden (Leiden), with a Palaeography of Abnormal Hieratic Signs and Sign Groups, Fascicle I: Papyri from London, Brooklyn, Cairo and Leiden, Leiden.

Donnat, S., 2009, "Le rite comme seul référent dans les lettres aux morts. Nouvelle interprétation du début du Cairo Text on Linen" BIFAO 109, 61-93.

Donnat, S., 2010, "Written pleas to the invisible world: Texts as media between the living and dead in pharaonic Egypt", in A. Storch (Hrsg.), Sprache und Geschichte in Afrika. Perception of the invisible: religion, historical semantics and the role of perceptive verbs, SUGIA 21, 51-80.

Donnat, S., 2012, “Gestion in absentia de domaine familial: à propos des lettres aux morts et des documents d'Héqanakht", in A. Gasse, F. Servajean, C. Thiers (eds.), Et in Ægypto et ad Ægyptum: recueil d'études dédiées à Jean-Claude Grenier, vol. II, Montpellier, 227-242.

Donnat, S., 2014, Écrire à ses morts. Enquête sur un usage rituel de l'écrit dans l'Egypte pharaonique, Grenoble.

Edel, A., 1955/1964, Altägyptische Grammatik, Analecta Orientalia $34 / 39$.

Edel, A., 1987, “Eine althieratische Liste von Grabbeigaben aus einem Grab des späten Alten Reiches der Qubbet el-Hawa bei Assuan", NAGW 1987/6, 93-105.

Edel, A., 1992, “Unpublizierte althieratische Elephantine-Papyri aus Strassburg”, in I. Gamer-Wallert, W.C. Helk (eds.), Gegengabe. Festschrift für Emma Brunner-Traut, Tübingen, 73-81.

Edel, A., 2008, Die Felsgräbernekropole der Qubbet el-Hawa bei Assuan. 1. Abteilung (aus dem Nachlass verfasst und herausgegeben von Karl-J. Seyfried und Gerd Viel), Paderborn.

Farout, D., 2004, “Une céramique inscrite: la lettre au mort de Qaou el-Kébir”, Égypte, Afrique \& Orient 36, 42-52;

Fecht, G., 1969, “Der Totenbrief von Nag“ ed-Deir”, MDAIK 24, 105-128.

Fischer, H.G., 1968, Dendera in the Third Millennium B.C.: Down to the Theban Domination of Upper Egypt, Augustin.

Fischer-Elfert, H.-W., 1994, "Vermischtes III.”, GM 143, 41-49.
Frandsen, P.J., 1992, “The letter to Ikhtay's coffin: O. Louvre Inv. No. 698”, in R. J. Demarée, A. Egberts (eds.), Village voices: proceedings of the symposium „Texts from Deir el-Medîna and their interpretation“, Leiden, May 31-June 1, 1991, Leiden, 31-49.

Gardiner, A.H., 1930, “A new Letter to the Dead”, JEA 16, 19-22.

Gardiner, A.H., 1935, The attitude of the ancient Egyptians to death and the dead, Cambridge.

Gardiner, A.H., K. Sethe, 1928, Egyptian Letters to the Dead, Mainly from the Old and Middle Kingdoms, London.

Gilula, M., 1969, “Negative sentences in a Letter to the Dead”, JEA 55, 216-217.

Goedicke, H., 1972, “The Letter to the Dead, Nag“ ed-Deir N 3500”, JEA 58, 95-98.

Goedicke, H., 1988, Old hieratic palaeography, Baltimore.

Goldwasser, 0., 1995, "On the Conception of the Poetic Form - A Love Letter to a Departed Wife: Ostracon Louvre 698”, in S. Izre'e, R. Drory (eds.), Language and Culture in the Near East, IOS 15, 191-203.

Grapow, H., 1915, “Über einen ägyptischen Totenpapyrus aus dem frühen Mittleren Reich”, SPAW 1915, 376-384.

Grieshammer, R., 1970, Das Jenseitsgericht in den Sargtexten, ÄA 20.

Griffith, F., 1889, The inscriptions of Siût and Dêr Rîfeh, London.

Guilmot, M., 1966, “Les Lettres aux morts dans l'Égypte ancienne”, RHR 170, 1-27.

Guilmot, M., 1973, “Lettre à une épouse défunte (Pap. Leiden I, 371)”, ZÄS 99, 94-103.

Gunn, B., 1930, "Review of Egyptian Letters to the Dead, mainly from the Old and Middle Kingdoms. Copied, translated and edited by Alan H. Gardiner and Kurt Sethe. London: at the Offices of the Egypt Exploration Society", JEA 16, 147-155.

Harris, M., 2001, Cultural Materialism. The Struggle for a Science of Culture, Walnut Creek-Lanham-London-New York (revised version).

Headland, T.N., 1990, “Introduction: A Dialogue Between Kenneth Pike and Marvin Harris on Emics and Etics", in T.N. Headland, K.L. Pike, M. Harris (eds.), Emics and Etics. The Insider/ Outsider Debate, Frontiers of Anthropology 7, Newbury Park-London-New Delhi, 13-27.

Janák, J., 2003, “Revealed but Undiscovered: a new Letter to the Dead”, JNES 62, 275-277.

Janson, R., G. Vittmann, 1992-93, “An Abnormal Letter to the Dead (P. Brooklyn 37.1799E)”, Enchoria 19/20, 23-43.

Janssen, J.J., Commodity Prices from the Ramesseum Period. An Economic Study of the Village of Necropolis Workmen at Thebes, Leiden 1975.

Jürgens, P., 1990, “Der Tote als Mittler zwischen Mensch und Göttern im Berliner Sargtexte-Papyrus. Ein Zeugnis inoffizieller Religion aus dem Mittleren Reich", GM 116, 51-63.

Kemp, B., 1975, Dating Pharaonic Cemeteries. Part I: Non-mechanical Approaches to Seriation, MDAIK 31, 259-291.

Lett, J., 1990, “Emics and Etics: Notes on the Epistemology of Anthropology", in T.N. Headland, K.L. Pike, M. Harris (eds.), Emics and Etics. The Insider/Outsider Deabate, Frontiers of Anthropology 7, Newbury Park-London-New Delhi, 132.

Miniaci, G., 2014a, Le Lettere ai Morti e altre storie di fantasmi nell'Antico Egitto, Testi del Vicino Oriente antico 8. 
Miniaci, G., 2014b, “The $m s k$ ' as "child's inheritance" (?) in the context of the Old Kingdom Seankhenptah's letter to the dead, Cairo JE 25975", EVO 37, 27-45.

Moreno Garcia, J.C., 2010, “Oracles, Ancestor Cults and Letters to the Dead: The Involvement of the Dead in the Public and Private Family Affairs in Pharaonic Egypt" in A. Storch (ed.), Sprache un Geschichte in Afrika. Perception of the invisible: religion, historical semantics and the role of perceptive verbs, SUGIA 21, 133-153.

Möller, G., 1912, Hieratische Paläographie. Die ägyptische Buchschrift in ihrer Entwicklung von der fünften Dynastie bis zur römischen Kaiserzeit. III, von der zweiundzwanzigsten Dynastie bis zum dritten Jahrhundert nach Chr., Vols. I-III, Leipzig.

Oréal, E. 2008, “«Bienvenue!» (Ptahhotep, maxime 22). Répartition des biens et salut individuel”, RdE 59, 335-356.

Piankoff, A., J.J. Clère, 1934, "A letter to the dead on a bowl in the Louvre”, JEA 20, 157-169.

Pike, K.L., 1954, Language in relation to a unified theory of the structure of human behaviour, $1^{\text {st }}$ ed., The Hague.

Pike, K.L., 1979, "On the extension of etic-emic anthropological methodology to referential units-in-context", in Lembaran Pengkajian Budaya 3, 1-36.

Posener-Kriéger, P., 1976, Les archives du temple funéraire de Néferirkarê-Kakaï (Les papyrus d’Abousir), Vol. II, BdE 65.

Quirke, S., 1988, “Letter to the Dead”, in S. D’Auria, P. Lacovara, C.H. Roehrig (eds.), Mummies \& magic: the funerary arts of ancient Egypt, Boston 1988, p. 106-107.

Ranke, H., 1935, 1949, 1977, Die ägyptischen Personennamen, vols. I-III, Glückstadt.

Regulski, I., 2014, “Middle Kingdom papyrus fragments from Asyut: a palaeographic comparison”, in U. Verhoeven (ed.), Neue Forschungen und Methoden der Hieratistik, Ägyptologische „Binsen“-Weisheiten I-II. Akten zweier Tagungen in Mainz im April 2011 und im März 2013, Abhandlungen der Akademie der Wissenschaften und der Literatur (in press).

Renfrew, C., 1987, Archaeology and Language. The Puzzle of Indo-European Origins, London.

Roccati, A., 1967, “Due lettere ai morti”, RSO 42, 323-328.

Roeder, G., 1961, Die ägyptische Religion in Texten und Bildern. Der Ausklang der ägyptischen Religion mit Reformation, Zauberei und Jenseitsglauben, Zürich-Stuttgart.

Schneider, H.D., 1981, Een brief voor Anchiry. Scenes uit een Egyptisch huwelijk of persoonlijk getuigenis over leven en dood in Oud-Egypte, Zutphen.

Seidlmayer, S.J., 2006, "Zum Verständnis der Liste von Grabbeigaben von der Qubbet el-Hawa" GM 208, 95-103.

Silverman, D.P., 1980, Interrogative Constructions with $I n$ and $I n-J w$ in Old and Middle Egyptian, Malibu.

Simpson, W.K., 1966, "The Letter to the Dead from the Tomb of Meru (N 3737) at Nag“ ed-Deir”, JEA 52, 39-52.
Simpson, W.K., 1970, "A late Old Kingdom letter to the dead from Nag’ Ed-Deir N 3500”, JEA 56, 58-64.

Simpson, W.K., 1970, “Addendum on the Letter to Meru (N 3737)", JEA 56, 62.

Simpson, W.K., 1981, "The Memphite Epistolary Formula on a Jar Stand of the First Intermediate Period from Nag Ed-Deir", in W.K. Simpson, W.M. Davis (eds.), Studies in Ancient Egypt, the Aegean, and the Sudan. Essays in honor of Dows Dunham on the occasion of his 90th birthday, June 1, 1980, Boston, 173-179.

Stauder, A., 2014, The Earlier Egyptian Passive: Voice and Perspective, LingAeg 14.

Szpakowska, K., 1999, “A Sign of the Times”, LingAeg 6, 163-166.

Szpakowska, K., 2003, Behind closed eyes: dreams and nightmares in ancient Egypt, Swansea.

Teeter, E., 2003, Ancient Egypt. Treasures from the Collection of the Oriental Institute University of Chicago, Chicago.

Trautmann, T., C.M. Sinopoli, 2006, "Excavating the Relations between History and Archaeology in South Asia”, in N. Yoffee, B.L. Crowell (eds.), Excavating Asian History: Interdisciplinary Studies in Archaeology and History, Tuscson.

Trigger, B.G., 1980, Gordon Child. Revolutions in Archaeology, London.

Vandier, J., 1950, Mo'alla: La tombe d'Ankhtifi et la tombe de Sébekhotep, BdE 18.

Verhoeven, U., 2003, “Post ins Jenseits - Formular und Funktion altägyptischer Briefe an Tote“, in A. Wagner (ed.), Bote und Brief. Sprachliche Systeme der Informationsübermittlung im Spannungsfeld von Mündlichkeit und Schriftlichkeit“, IAK-NWS 4, 31-52.

Vernus, P., 1986, “Aspect and morphosyntactic patterns in Middle Egyptian”, in: G. Englund and J. Frandsen (eds.), Crossroad: chaos or the beginning of a new paradigm (Papers from the conference on Egyptian grammar, Helsingor 28-30 May 1986). Copenhague, 375-388.

Vernus, 1996, "La position linguistique des Textes des Sarophages", in H. Willems (ed.), The World of the Coffin Texts. Proceedings of the Symposium Held on Occasion of the 100th Birthday of Adriaan de Buck. Leyde, December 17-19, 1992, EgUit 9,

Wente, E.F., 1975-1976, “A misplaced letter to the Dead”, in P. Naster (Hg.), Miscellanea in Honorem Josephi Vergote, OLP 6/7, 595-600.

Wente, E.F., 1990, Letters from Ancient Egypt, Atlanta.

Willems, H., 1991, “The end of Seankhenptah's Household (Letter to the Dead Cairo JDE 25975)", JNES 50/3, 183-191.

Willems, H., 2008, Les Textes des Sarcophages et la Démocratie. Eléments d'une histoire culturelle du Moyen Empire égyptien. Quatre conférences présentées à l'Ecole Pratique des Hautes Etudes. Section de Sciences religieuses, Mai 2006, Paris. 


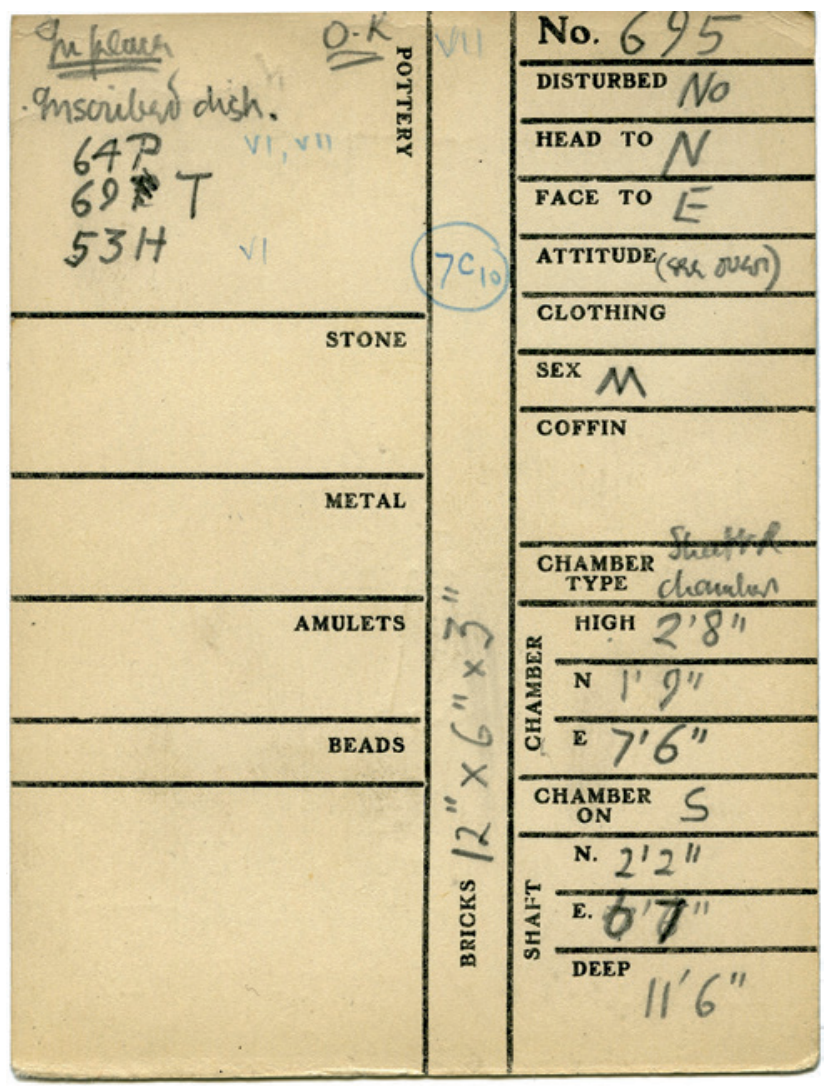

Fig. 1: Tomb-card of tomb Qau 7695, recto $\odot$ Courtesy of the Petrie Museum of Egyptian Archaeology, UCL.

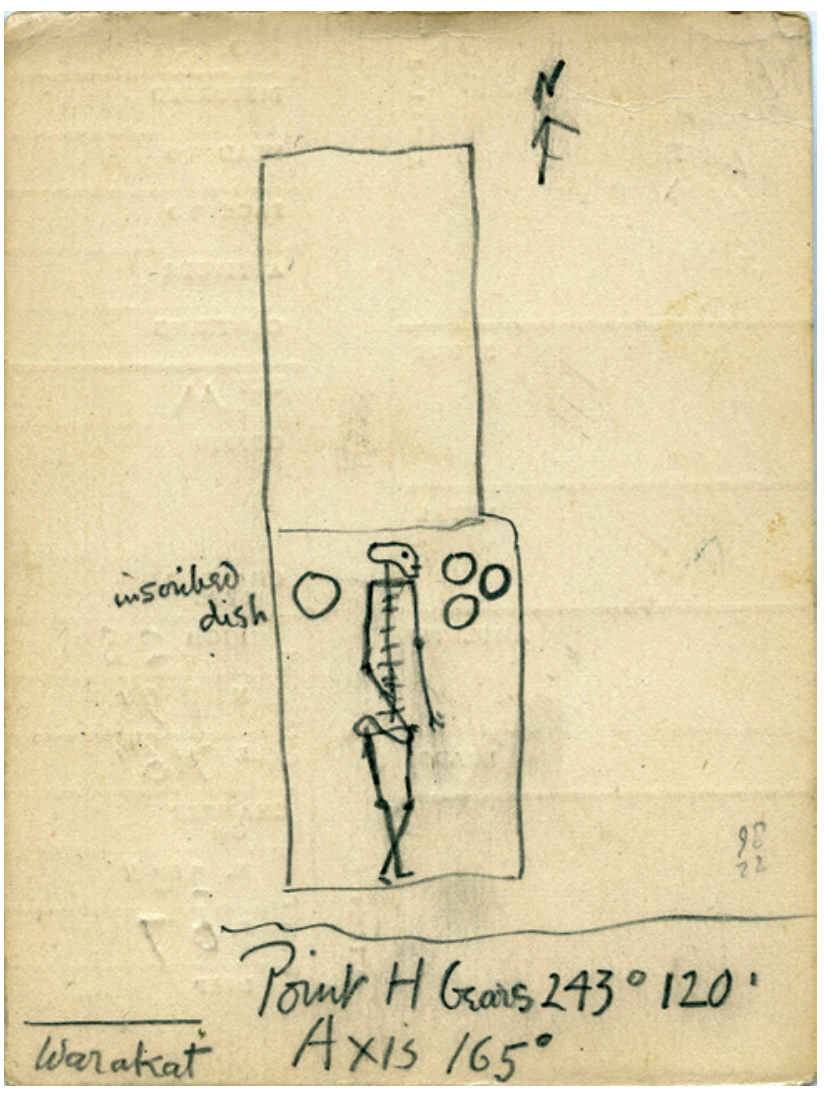

Fig. 2: Tomb-card of tomb Qau 7695, verso @ Courtesy of the Petrie Museum of Egyptian Archaeology, UCL. 


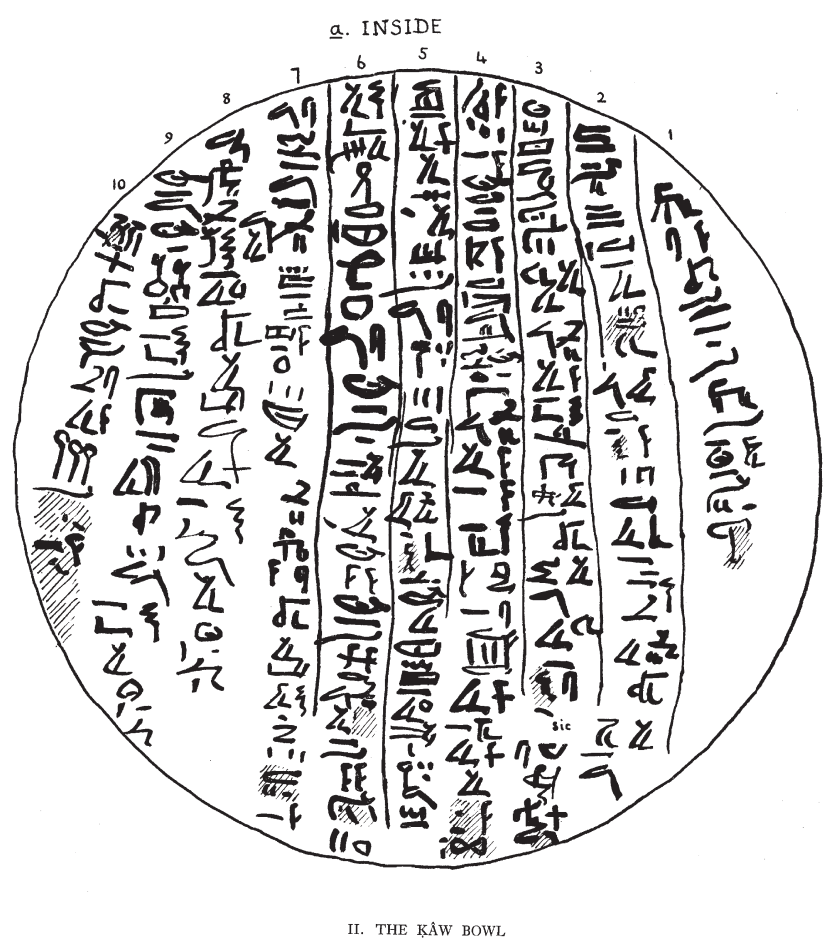

Fig. 3: The Qau bowl UC16163 (inside). Fac-simile of hieratic inscription, from Gardiner and Sethe 1928, pl. II.

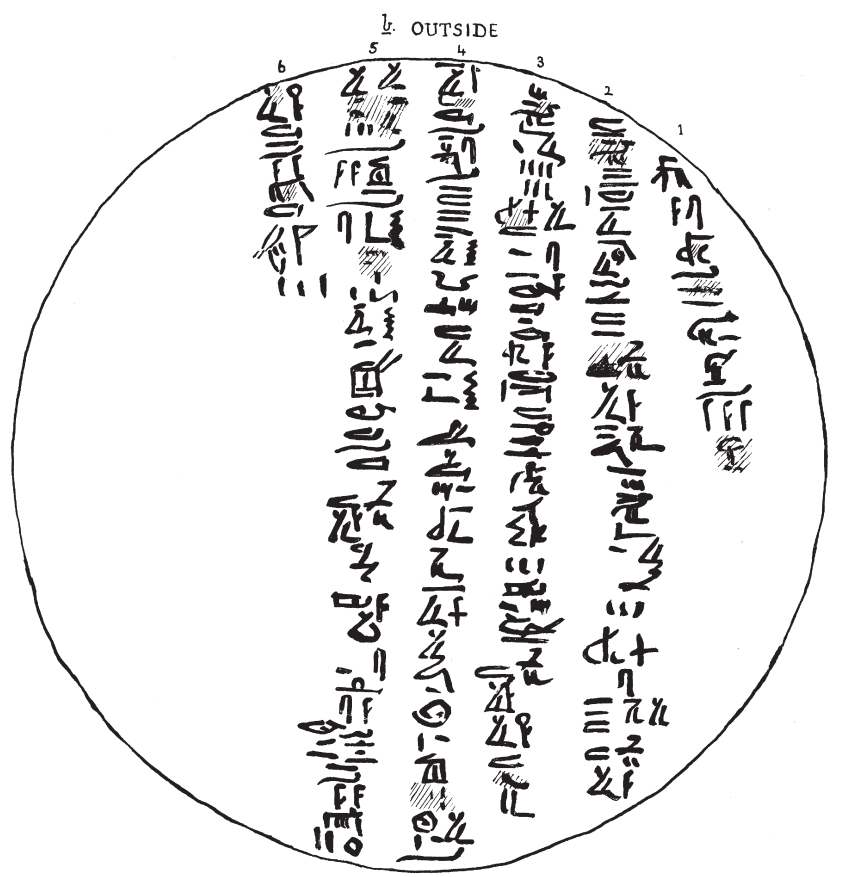

Fig. 05: The Qau bowl UC16163 (outside). Fac-simile of hieratic inscription, from Gardiner and Sethe 1928, pl. III.

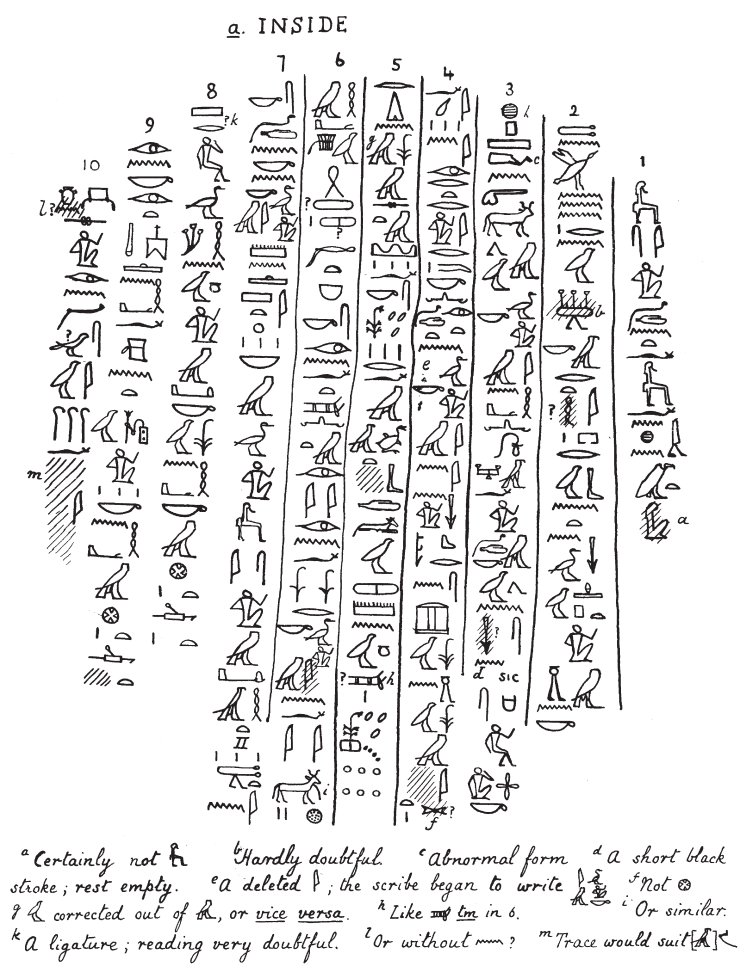

Fig. 4: The Qau bowl UC16163 (inside). Hieroglyphic transcription from Gardiner and Sethe 1928, pl. II.A.

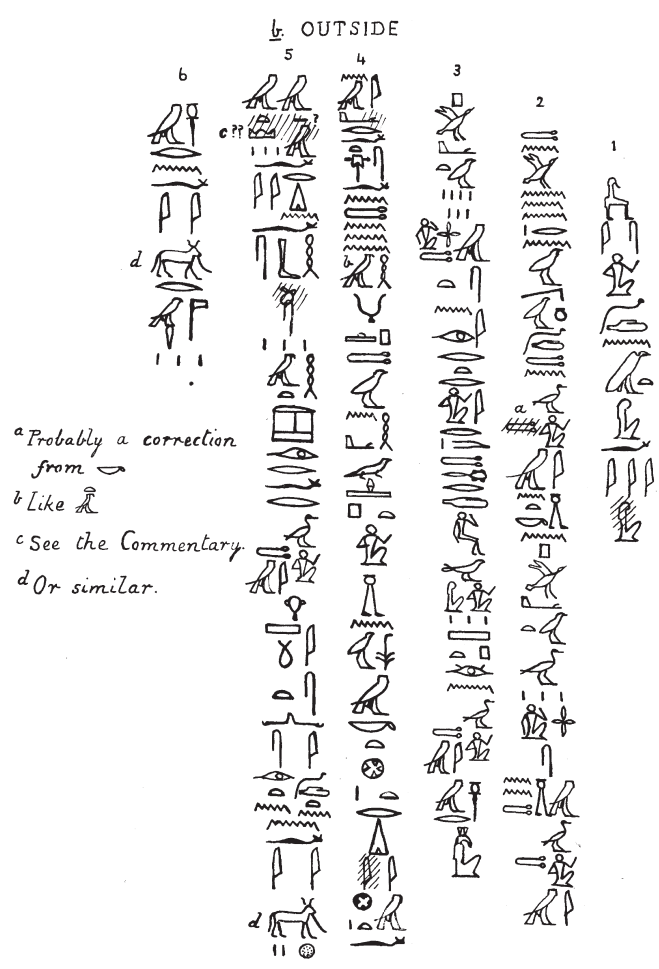

Fig. 06: The Qau bowl UC16163 (outside). Hieroglyphic transcription, from Gardiner and Sethe 1928, pl. III.A. 


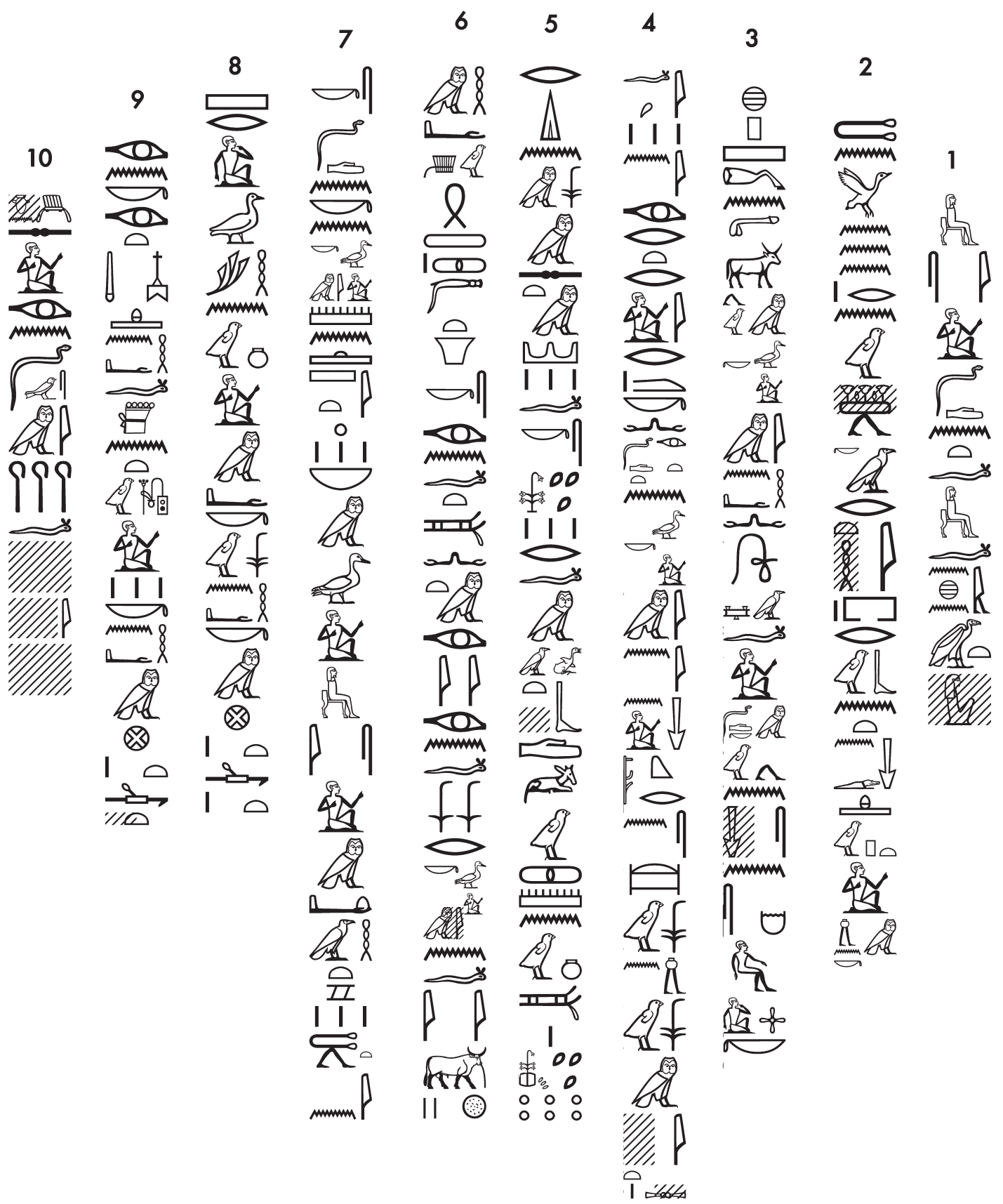

Fig. 07: Hieroglyphic transcription of the inner text with the editing proposed in the article. 


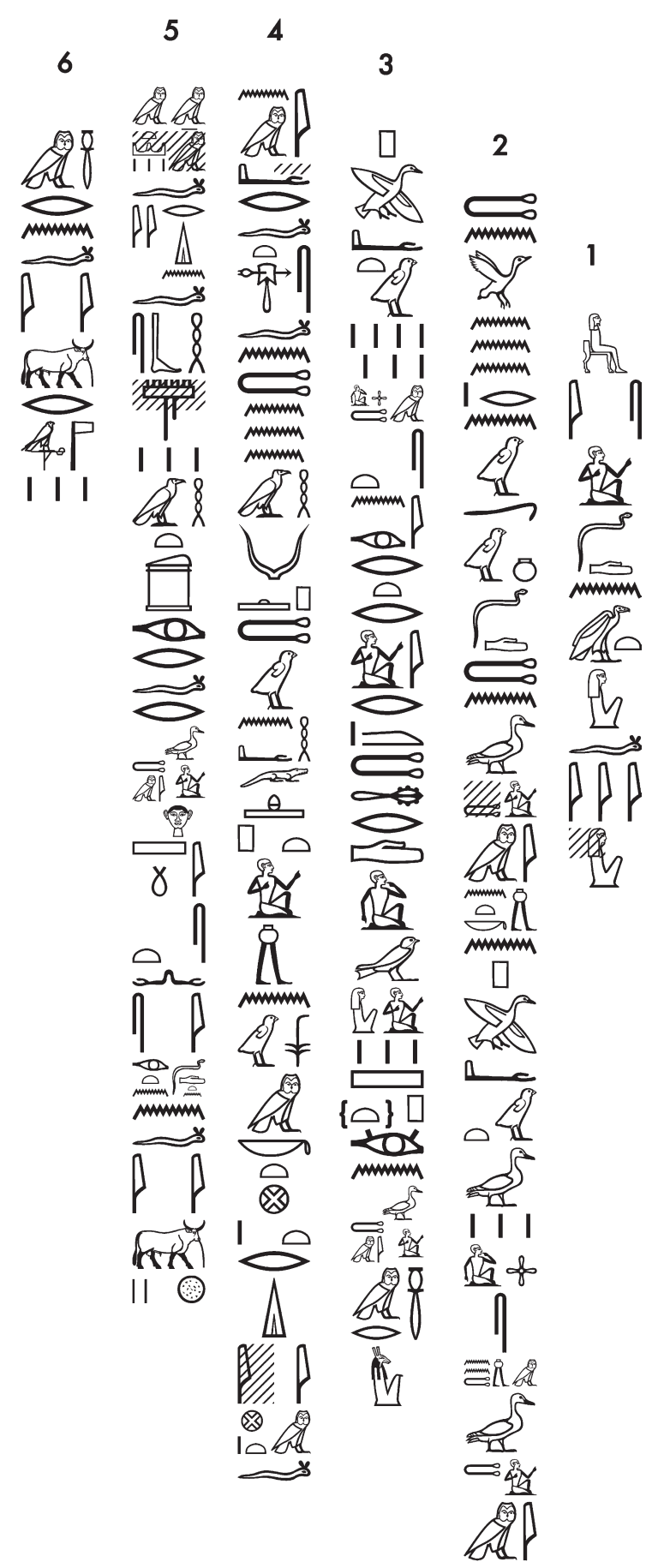

Fig. 08: Hieroglyphic transcription of the outer text with the editing proposed in the article. 